\title{
The Piedra Chamana fossil woods (Eocene, Peru)
}

\author{
D.W. Woodcock ${ }^{1, *}$, H.W. Meyer $^{2}$, and Y. Prado ${ }^{3}$ \\ ${ }^{1}$ Marsh Institute of Clark University, 650 Main Street, Worcester, MA 01610, U.S.A. \\ ${ }^{2}$ U.S. National Park Service, Florissant Fossil Beds National Monument, P.O. Box 185, \\ Florissant, CO 80816, U.S.A. \\ ${ }^{3}$ Museo de Historia Natural, Universidad Nacional Mayor de San Marcos, Av. Arenales 1256, \\ Lima 14, Peru \\ *Corresponding author; e-mail: dwoodcock@clarku.edu
}

\begin{abstract}
The fossil woods and leaves of the Fossil Forest Piedra Chamana represent a diverse assemblage of plants dating to $39 \mathrm{Ma}$ (late Middle Eocene). The fossils are preserved in an ashfall and overlying lahar deposits near the small village of Sexi in the northern Peruvian Andes (central Cajamarca). The assemblage includes dicot wood types and leaf morphotypes, as well as a diversity of monocot material. The 30 dicot wood types are referred to the families Acanthaceae, Anacardiaceae, Apocynaceae, Combretaceae, Cordiaceae, Dipterocarpaceae, Euphorbiaceae, Fabaceae, Lechythidaceae, Lythraceae, Malvaceae, Melastomataceae, Muntingiaceae, Rubiaceae, Rutaceae, and Sapindaceae. Described herein are descriptions of the first 17 wood types that have been assigned to the families Acanthaceae through Lythraceae; descriptions of the additional wood types will appear in a later paper. The paleovegetation can be characterized as lowland tropical forest with a dry aspect based on preliminary analysis of floristic affinities and wood anatomical characteristics of the fossils.
\end{abstract}

Keywords: Fossil forest, fossil leaves, wood anatomy, Sexi, Peruvian Andes.

\section{INTRODUCTION}

The Piedra Chamana Fossil Forest is located in the northern Peruvian Andes near the village of Sexi $\left(79^{\circ} 10^{\prime} \mathrm{W}, 6^{\circ} 35^{\prime} \mathrm{S}\right)$ at an elevation of $\sim 2800 \mathrm{~m}$ (Fig. 1A). ${ }^{40} \mathrm{Ar} /{ }^{39} \mathrm{Ar}$ dating of volcaniclastic rocks associated with the fossils has established an age of $39 \mathrm{Ma}$ (late Middle Eocene) for the fossils (Woodcock et al. 2009); the paleolatitude of the site was $\sim 15^{\circ} \mathrm{S}$ (van Hinsbergen et al.2015). Significant uplift occurred in the region at the time of the Andean orogeny beginning at $\sim 12 \mathrm{Ma}$ (Hoorn et al. 2010).

The Paleogene age of the assemblage places it relatively early in the diversification of Neotropical lowland forests during the period of Cenozoic warmth (Zachos et al. 2001) and before the rise of the Andes. Pollen records from northern South America provide a record of variations in number of morphospecies throughout the Paleogene and a peak in diversity in the early to middle Eocene (Jaramillo et al. 2006), but there are few comparable macrofossil assemblages for this period. Pollen and leaves from 


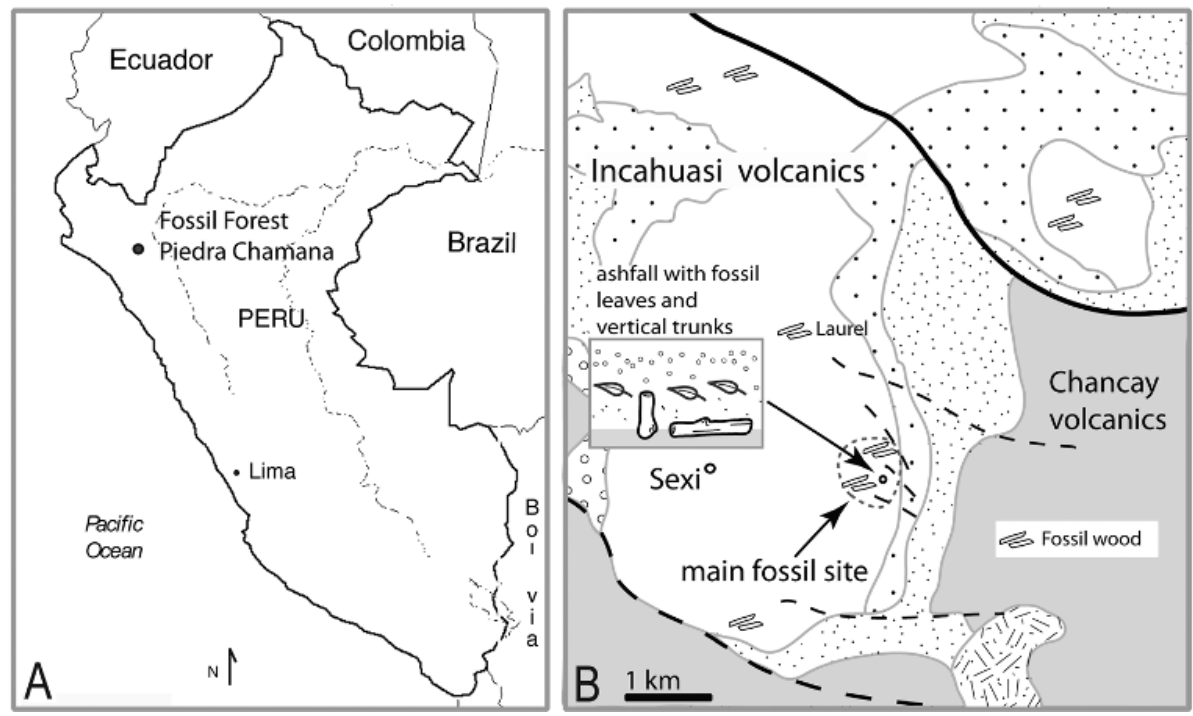

Figure 1. A: Geographical location of the fossil forest within Peru with reference to Lima. B: Map of the fossil sites (main part of the site and other areas where fossils have been found) associated with Incahuasi unit $2 b$ (unshaded area on the map, after Navarro et al. 2012). Solid and dashed lines represent known and inferred faults.

Colombia's Cerrejón Formation, older than the Piedra Chamana fossils at 58 Ma (late Middle Paleocene, paleolatitude of $5^{\circ} \mathrm{N}$ ), are floristically similar to modern tropical forests at the familial level (with prevalent legumes) and are considered the earliest record of Neotropical rainforest based on leaf morphology and floristics (Wing et al. 2009). At higher southern latitudes of the continent, the rich fossil record from Patagonia includes early to middle Eocene (48-52 Ma) leaf floras from central Patagonia showing the presence of diverse (temperate/subtropical) rainforest with megatherm dicots, palms, and gymnosperms during the Paleocene-Eocene Thermal Maximum (Wilf et al.2005; Wilf et al. 2013) and an in situ late-Oligocene (25-26 Ma) fossil forest in northern Patagonia dominated by Nothofagoxylon (Brea et al. 2015). Apart from numerous records from the Paleogene of Patagonia (Herbst et al. 2007; Brea et al.2008; Raigemborn et al. 2009), the majority of fossil woods described from South America (and also Mexico and Central America) are Cretaceous or Neogene in age. Most of the fossil woods generally comparable to the Sexi assemblage in age and tropical/near-equatorial occurrence are from Africa or Asia.

The fossiliferous strata at Sexi include two lahar deposits and an underlying ashfall deposit (Incahuasi volcanics unit 2b; Woodcock et al. 2009; Navarro et al. 2012). The majority of the woods collected were associated with the lahar deposits in the main part of the fossil site where a large amount of fossil wood occurs on the surface, covering an area of $1.0 \times .05 \mathrm{~km}^{2}$ (Fig. 1B). At this locality there are also trunks in a vertical position representing a forest buried in situ by the ashfall, and at one location we excavated fossil leaves occurring in direct proximity to the in situ trees in the same ashfall deposit. The 
leaves, mostly fragmentary and often not exceptionally well preserved, are dominated by one dicot morphotype resembling modern leaves of Avicennia L. (Acanthaceae, Fig. 3) and also include leaves referable to Anacardiaceae and Malvaceae.

The dicot material comprises approximately 30 wood types and 20-25 leaf morphotypes. Monocots are represented by stems, petioles, and leaves of an additional 10-12 taxa. The dicot woods are provisionally referred to Acanthaceae, Anacardiaceae, Apocynaceae, Combretaceae, Cordiaceae ( Boraginaceae), Dipterocarpaceae, Euphorbiaceae, Fabaceae, Lecythidaceae, Lythraceae, Malvaceae, Melastomataceae, Muntingiaceae, Rubiaceae, Rutaceae, and Sapindaceae. In this first paper we describe 17 wood types for families Acanthaceae through Lythraceae. Although comparisons were made to both modern and fossil woods, the main point of reference for comparative purposes are modern woods because of the more complete information available in descriptions and summary treatments. Previously described fossil woods are referenced where they show significant correspondence (i.e. anatomical similarity) to the fossil specimens.

In the conclusions we summarize evidence suggesting that the fossils represent a coastal to near-coastal lowland forest assemblage and provide a brief characterization of the paleovegetation based on the anatomy and likely floristic affinities of the woods. Separate contributions will describe the remaining 13 dicot wood types and provide more detailed analyses of the floristics and paleoenvironment.

\section{MATERIALS AND METHODS}

All samples described are from the main part of the fossil site (Fig. 1) except when noted. The majority of the woods are associated with the lahar and are generally better preserved than the in situ material, which is associated with the ashfall deposit. However some in situ material has been included and is indicated accordingly. The silicified woods were cut, and petrographic thin sections prepared, using standard techniques. Sample information includes specimen diameter or estimated diameter based on the gross anatomy (curvature of growth rings when present, convergence of rays toward the pith) assuming a generally circular cross section. In those specimens where the stele is asymmetric, measurements are given for the narrowest and widest diameter. Descriptions of the woods are based on IAWA terminology (IAWA Committee 1989). Quantitative characters are generally given as mean values \pm standard deviation. Vessel diameter was obtained by measuring all vessels within a rectangular area with fixed tangential dimension of $0.4 \mathrm{~mm}$ and a radial dimension that was varied so that a minimum of 60 vessels could be included. In this way, the diameter distributions could be tested for non-normality and the occurrence of more than one population of vessel diameter determined. In cases where the distributions are significantly nonnormal, vessel diameter is given in terms of modal (most frequent) values rather than mean \pm standard deviation. Vessel density is the average of 10 fields. An attempt was made to include vessel tails in the measurement of vessel element length but this was not always possible. The measurements of fiber length have been included in some cases and are less accurate than measurements based on macerations but have been included for completeness. Inclusions are noted only when they do not appear to be 
either secondary or related to preservational processes. Silica bodies are noted when occurring intracellularly and in specific locations rather than throughout the wood (in which case they are more likely to be preservation related).

Assessments of affinity relied on information in the InsideWood database (InsideWood 2004-onwards; Wheeler 2011), the Commercial Timbers database (Richter \& Dallwitz 2000-onwards), Metcalfe \& Chalk (1950), family level treatments and other published wood anatomical studies, regional wood atlases (including Détienne \& Jaquet 1983, Acevedo \& Kikata 1994, Miller \& Détienne 2001, and Sonsin et al.2014), descriptions of fossil woods, and the list of fossil wood names compiled by Gregory et al. (2009). The Bailey-Wetmore Wood and Slide Collection at Harvard (Aw), the wood slide collection at the Smithsonian Museum of Natural History, and wood slides in the private collection of Woodcock were also consulted. The InsideWood database was used to test for correspondences and also to try and identify unique suites of characters shared by the fossil and those taxa considered to be closest anatomical relatives. Discussions utilize information about wood anatomical characteristics at the supergeneric (family, tribe, etc.) and genus or species level to evaluate potential relationships, with particular note being taken of dissimilarities with respect to coded IAWA characters, and similarities and dissimilarities with respect to other (non-coded) characters. Recent taxonomic revisions are cited where appropriate.

With regard to taxonomic assignment of the fossil material, we adopted the following approach: Where anatomical similarities with extant genera are very close, the fossil material has been assigned to the relevant genus and described as a new species. In cases where the attributions are to non-New World taxa or the identifications seem less clear for reasons discussed, the material is referred provisionally to extant taxa and the name is preceded by 'cf.'.

Collections were made under permits no. C/073-2001 and 513-2009 from the Peruvian National Institute of Culture and specimens now contribute to the permanent collections in the Department of Paleontology of Invertebrates and Paleobotany of the Museo de Historia Natural/Universidad Mayor Nacional San Marcos in Lima. Two designations are used in the catalog numbers: specimens with the prefix S were collected by Woodcock whereas those without a letter prefix were collected by Guillermo Morales or Isabel Prado of the research staff at the museum. More specific information about specimens or localities can be obtained from curators of the collection.

\section{DESCRIPTIONS}

\section{Acanthaceae}

AvicENNIA L.

Avicennia sexiensis Woodcock, Meyer et Prado, sp.nov. (Fig. 2)

Diagnosis: Wood with bands of parenchyma and included phloem. Vessels solitary and in radial multiples up to $12-15$ vessels, mean tangential diameter $\sim 60 \mu \mathrm{m}$, perforations simple, intervessel pits alternate, vessel-ray pits similar to intervessel pits. Fibers non-septate and occasionally septate. Axial parenchyma scanty paratracheal and in anastomosing bands with included phloem. Phloem strands $100 \times 150-200 \mu \mathrm{m}$ 


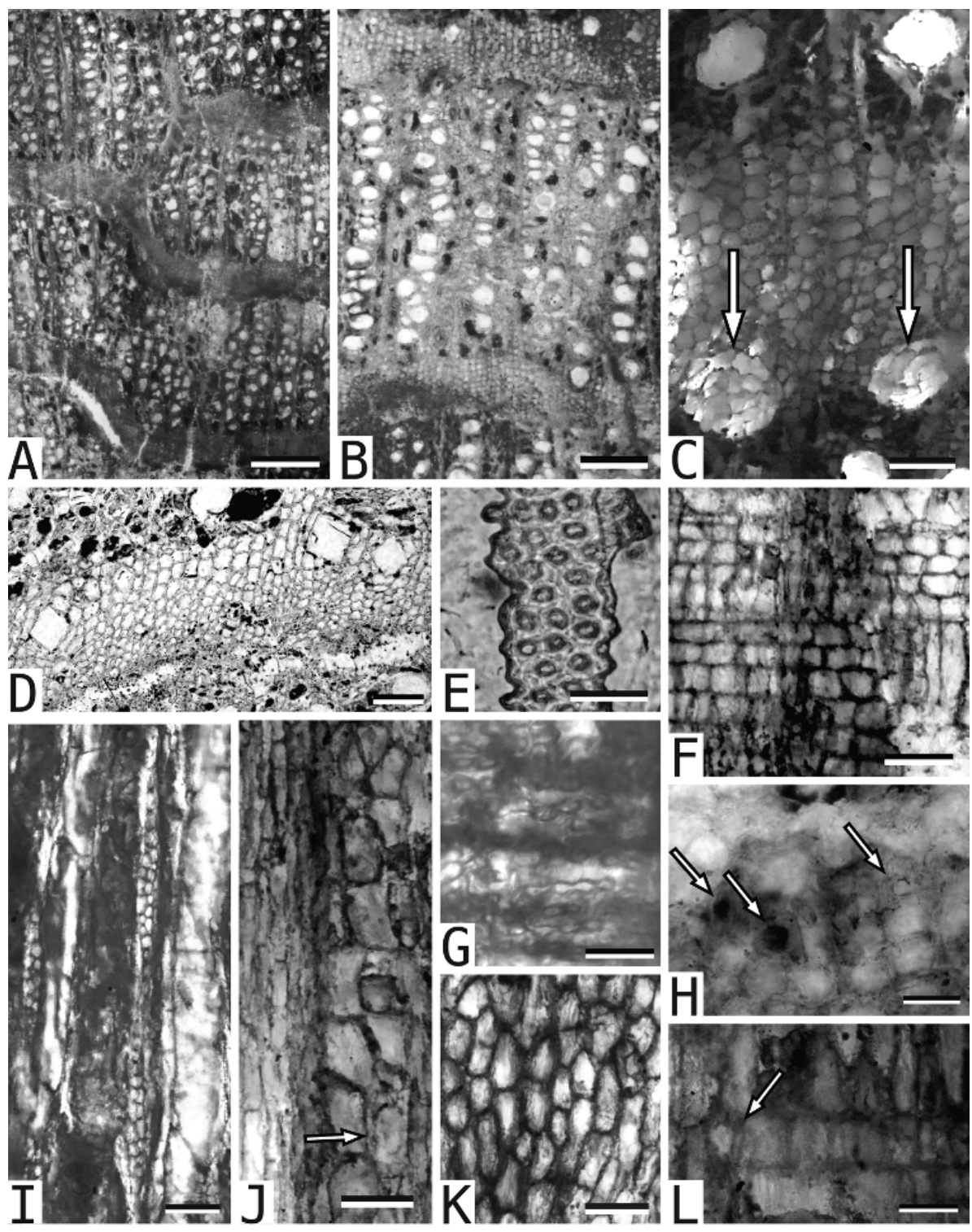

Figure 2. Avicennia sexiensis Woodcock, Meyer et Prado, sp. nov. - A: Anastomosing bands of conjunctive parenchyma with included phloem, transverse section (TS). - B: Vessels solitary and in radial multiples, TS . - C: Parenchyma band with included phloem strands (arrows), TS . D: Cubic crystals, TS. - E: Intervessel pits alternate, oval-shaped, tangential longitudinal section (TLS). - F: Rays of mixed upright, procumbent, and square cells, radial longitudinal section (RLS). - G: Vessel-ray pits similar to intervessel pits, RLS. - H: Sclereids in parenchyma band (arrows), TS. - I: Rays 2-3-seriate, TLS. - J: Parenchyma band with elongate parenchyma cells adjacent to squarish cells, possible sclereid (arrow), RLS. - K: Conjunctive parenchyma, TLS. - L: Sclereid at end of ray (arrow), RLS. - Scale bars $=0.5 \mathrm{~mm}$ in A; $250 \mu \mathrm{m}$ in B; $100 \mu \mathrm{m}$ in $\mathrm{D}, \mathrm{I} ; 75 \mu \mathrm{m}$ in $\mathrm{C}, \mathrm{K} ; 50 \mu \mathrm{m}$ in $\mathrm{F}, \mathrm{J} ; 20 \mu \mathrm{m}$ in $\mathrm{E}, \mathrm{G}, \mathrm{H}, \mathrm{L}$. 
(radial $\times$ tangential dimensions) occurring in the inner part of the parenchyma band; parenchyma cells dimorphic in radial view, narrow and axially elongate on the inner side of the band and wider and square to rectangular on the outer side of the band. Rays 1-3-seriate with procumbent, square, and upright cells mixed throughout. Sclereids present in the parenchyma bands.

Etymology: The specific epithet refers to the type locality.

Holotype: $\mathrm{S} 1$ (7-8 cm in diameter). Other material: $\mathrm{S} 39(6 \times 10 \mathrm{~cm}), \mathrm{S} 45 \mathrm{~A}(5 \times 6.5)$, S50 $(4 \mathrm{~cm})$, S5 $1(4 \mathrm{~cm})$, S52 $(3.5 \times 4)$, S55 $(6 \times 5 \mathrm{~cm})$. Samples S1, S39, and S55 are from the main part of the site; the other four samples are from Laurel, approximately $2 \mathrm{~km}$ to the $\mathrm{N}$ (Fig. 1B). Much of this material is poorly preserved.

Type locality: Piedra Chamana Fossil Forest main site, Sexi, Peru, associated with the lahar deposits.

Description: Wood diffuse porous, with bands of parenchyma and included phloem (Fig. 2A,C). Vessels solitary and in radial multiples (Fig. 2B) up to 12-15 vessels in length, tangential diameter $62 \pm 14 \mu \mathrm{m}, 53$ per $\mathrm{mm}^{2}$; vessels round to angular in outline, perforations simple, end walls oblique; intervessel pits alternate, oval to round, (3-)5-7 um (Fig. 2E); vessel-ray pits bordered, similar in size and shape to intervessel pits (Fig. 2G); vessel element length $166 \pm 65 \mu \mathrm{m}$. Fibers at least occasionally septate, very thick-walled, pitting not observed. Axial parenchyma scanty paratracheal and in irregularly concentric, anastomosing bands of conjunctive tissue 6-14 cells wide with included phloem (Fig. 2A,B,C). Phloem strands $100 \times 150-200 \mu \mathrm{m}$ (radial $\times$ tangential dimensions) (Fig. 2C), evenly spaced, on the inner side of the parenchyma bands; contact between inner edge of the parenchyma band and adjacent xylem sinuous, bulging toward the inner side of the stele near the phloem strands; on the inner side of the band, parenchyma cells narrow and axially elongate (Fig. 2J); on the outer side, cells wider, square to rectangular in radial view (Fig. $2 \mathrm{~J}$ ) and irregularly shaped ( \pm isodiametric to somewhat axially elongate) and oriented in tangential view (Fig. $2 \mathrm{~K}$ ). Rays 1-3-seriate (Fig. 2 I), with procumbent, upright, and square cells mixed throughout (Fig. 2F); rays widening near the outer side of the parenchyma bands in transverse view and appearing mostly discontinuous across the bands; ray height $344 \pm 88 \mu \mathrm{m}, 4.4 \pm 1.3$ per mm. Yellowish deposits in vessels and sporadically throughout the wood. Some indication of sclereids in the parenchyma bands (Fig. $2 \mathrm{H}, \mathrm{J}$ ) and at the end of the rays adjacent to the parenchyma band (Fig. 2L). Very large cubic crystals (Fig. 2D) in cells of the parenchyma bands.

Affinity: In the InsideWood database, the combination of vessels in radial multiples $>4$ and 50-100 $\mu \mathrm{m}$ diameter, rays 1-3-seriate and of mixed square, upright, and procumbent cells, and concentric included phloem (IAWA characters 10, 41, 97, 109, 133) occurs in Avicennia (Acanthaceae) and Maerua (Capparaceae). Maerua (M.oblongifolia (Forssk.) A. Rich., Capparaceae) shares many coded characters with the fossil but differs in having vessels of two distinct sizes and rays that are $>1 \mathrm{~mm}$ high and wider. Avicennia appears most similar to the fossil, sharing the additional characters of round to oval intervascular pits, parenchyma bands that are anastomosing with phloem strands on the inner side and forming a sinuous boundary with the adjacent xylem, and rays that widen where they join the parenchyma band on the outer side (Zamski 1979; 
InsideWood 2004-onwards). In radial section, cells within the parenchyma bands in Avicennia are axially elongate on the inner side of the band and square to rectangular on the outer side (and irregularly isodiametric in tangential view), as described in greatest detail for Avicennia marina (Forssk.) Vierh. (Sun \& Suzuki 2000) and seen in material in InsideWood (e.g. Avicennia germinans (L.) L.; Kw14958) and in the Harvard wood slide collections as well as in the fossil. A pattern of secondary growth in Avicennia in which the phloem strands differentiate after the successive cambia cease to be active and stay uncrushed and functional (Zamski 1979) may account for preservation of the phloem strands in the fossil. The parenchyma bands in Avicennia generally have a sclereid layer 1 to 2 or more cells wide but which is less well developed and sometimes discontinuous in some species (A.germinans, Aw). This feature is not very evident in the fossil, although there is some evidence of sclereids in the parenchyma band. Vessels are narrower and in longer radial multiples and phloem strands narrower than in most Avicennia species but within the range seen in A. germinans (Détienne \& Jacquet 1983).

The large crystals evident in transverse section appear to be halite pseudomorphs. They are cubic in form, unlike crystals of calcium oxalate, which tend to be rhomboidal ("prismatic") or, less commonly, elongate to acicular or compound (Carlquist 1988) and rarely reach the size of the crystals seen in the fossil. Halite pseudomorphs have been reported in fossil wood from the Oligocene Sweet Home fossil forest in Oregon (Staples 1950; Gregory 1968). Halite crystals are often present in wood in saline environments (Arango \& Green 2011) but, being water soluble, are unlikely to be present in wood slides prepared by normal microtechnique. In Avicennia, salt is present in the water column and is excreted through specialized glands in the leaves, which often have conspicuous halite crystals on the surface (Tomlinson 1994).

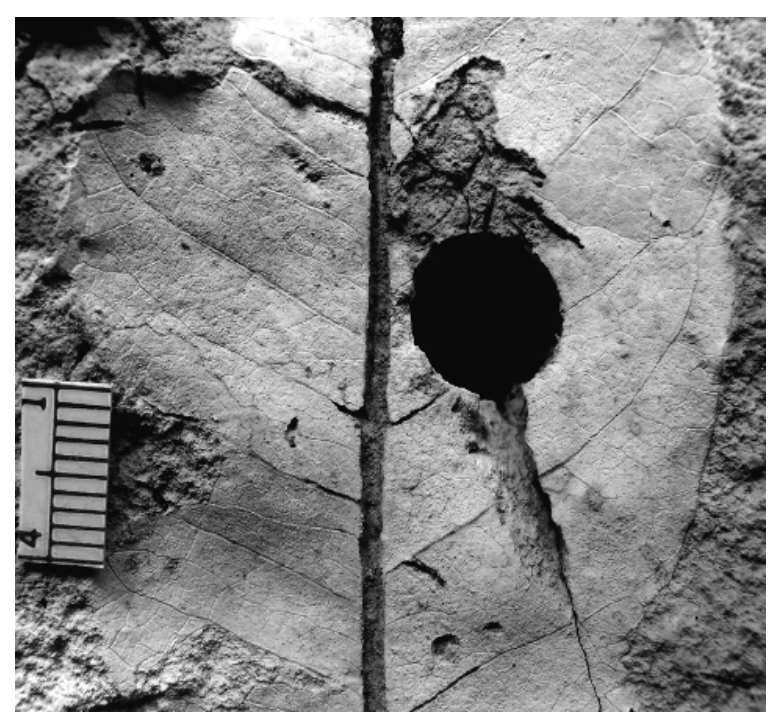

Figure 3. Fossil leaf showing probable correspondence to Acanthaceae - Avicennia. The hole is probably due to an accretionary lapillus (accretion of wet ash). - Scale bar $=1 \mathrm{~cm}$. 
The mangrove genus Avicennia occurs along tropical and warm-temperate coastlines worldwide, with A. germinans the most widely distributed species in the New World. The only other fossil wood record of the genus is from the Miocene of New Zealand (Sutherland 2003). This identification was based on presence of concentric phloem and similarity to the New Zealand mangrove Avicennia marina var. resinifera (G. Forst.) Bakh.

The fossil exhibits significant similarities with A. germinans but has a less well developed sclereid layer and is named to a newly erected species within Avicennia.

The most common leaf from the site (Fig. 3) has morphological characteristics consistent with Avicennia. Characters include: size microphyllous to notophyllous; margin entire, revolute; midvein thick, raised three-dimensionally in basal half; secondaries weakly brochidodromous; intersecondaries distinct, course often notably irregular or sinuous, length $>50 \%$ of subjacent secondaries, typically one per intercostal area, sometimes branching admedially to form epimedial tertiaries; tertiaries and intersecondaries often branching and thinning admedially. The small secretory salt glands that occur on Avicennia leaves were not observed in the fossils.

\section{Anacardiaceae}

Anacardiaceae cf. Mangifera (Fig. 4)

Growth rings present, marked by radially flattened fibers (Fig. 4D) and discontinuous parenchyma bands. Wood diffuse porous (Fig. 4A). Vessels solitary ( $65 \%)$ and in radial multiples of 2-4; tangential diameter $232 \pm 34 \mu \mathrm{m}, \sim 1$ per $\mathrm{mm}^{2}$, circular to oval in transverse section, perforations simple, end walls transverse; intervessel pits crowded, alternate, polygonal, $7-12 \mu \mathrm{m}$, apertures oval to slit-like and elongate (Fig. 4J); vessel-ray and vessel-axial parenchyma pits with reduced borders, the same size and shape as intervessel pits to somewhat enlarged (Fig. 4C); vessel element length $331 \pm 95 \mu \mathrm{m}$. Fibers generally non-septate, occasionally with thin septae (Fig. 4E), very thin-walled; pitting not observed; length $720 \pm 95 \mu \mathrm{m}$. Axial parenchyma scanty paratracheal and irregularly aliform with narrow wings $1-2(-3)$ cells wide (Fig. 4A,B), also in short bands 1-2(-3) cells wide occurring irregularly and at growth ring boundaries (Fig. 4K), not easily differentiated from fibers; in strands of 2-10 cells (Fig. 4F); paratracheal parenchyma wider and strands longer. Rays 1-3-seriate (Fig. 4G); uniseriate rays 1-6 cells high, low (1-3 cells long) rays of upright/square and high procumbent cells; multiseriate rays more frequent, composed of all procumbent cells or, more commonly, with one marginal row of upright, square, or high procumbent cells (Fig. 4H); upright cells often with distal projections (Fig. 4 I), height $356 \pm 165$ $\mu \mathrm{m}, \sim 3$ per $\mathrm{mm}$. Vessels with dark contents. Small dark globules in ray cells.

Specimen: S124 (25 cm in diameter). Other material: S113 $(25 \mathrm{~cm})$.

Affinity. In the InsideWood database, the combination of large intervessel pits, rounded or angular vessel-ray pits with reduced borders, septate and non-septate fibers, aliform paratracheal parenchyma, axial parenchyma in strands of 2-8, and rays exclusively 13 cells wide (IAWA characters 27, 31, 65, 66, 80, 91, 92, 93, 97, with 98 absent) occurs only in Anacardiaceae (Anacardium, Comocladia, Mangifera, Mauria, Pseudospondias). Growth rings marked by radially flattened latewood fibers is typical 

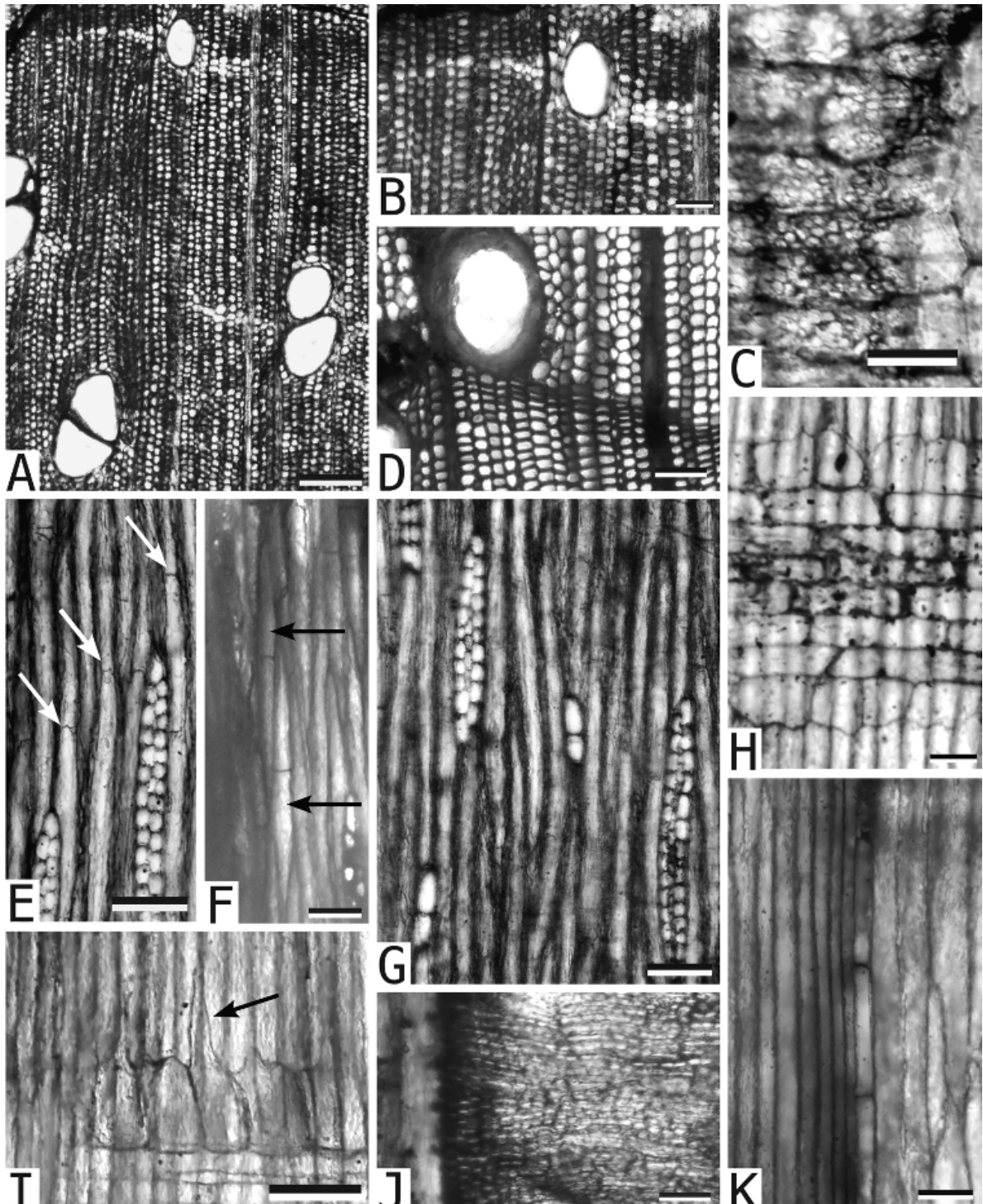

I lithifftan $\mathrm{J}$

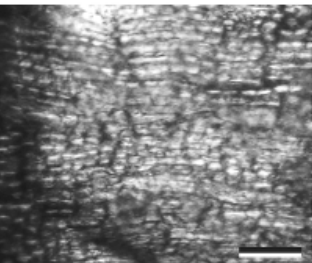

Figure 4. Anacardiaceae cf. Mangifera. - A: Wood diffuse porous, vessels solitary and in radial pairs, TS. - B: Fibers very thin-walled, paratracheal parenchyma narrowly winged-aliform, TS. - C: Vessel-ray pits with reduced borders, RLS. - D: Growth ring boundary marked by radially flattened fibers, TS. - E: Septate fibers (arrows), TLS. - F: Axial parenchyma in strands of 2 (arrows), TLS. - G: Rays 1-3-seriate, some very low, TLS. - H: Rays of procumbent cells with one row of square to upright cells, RLS. - I: Marginal ray cells with axial projections (arrow), RLS. - J: Pits with elongate apertures, TLS. - K: Parenchyma along ring boundary, RLS. - Scale bars $=250 \mu \mathrm{m}$ in $\mathrm{A} ; 100 \mu \mathrm{m}$ in $\mathrm{B}-\mathrm{G} ; 50 \mu \mathrm{m}$ in $\mathrm{H}, \mathrm{I}, \mathrm{K} ; 40 \mu \mathrm{m}$ in $\mathrm{J}$. 
of the family (Terrazas 1994); conspicuous vessel-axial parenchyma pits similar to vessel-ray pits, banded and marginal parenchyma, and uniseriate rays 1 to 2(+) cells high also occur (Dong \& Baas 1993; Terrazas 1994). The distal projections on the marginal ray parenchyma can be seen in some included taxa (e.g., Comocladia, Inside Wood 2004-onwards) but do not appear to be a reliable diagnostic character for the genus (or within the family, T. Terrazas, personal communication). The fossil is most similar to Mangifera (Anacardioideae clade 4, Weeks et al.2014), a genus of canopy trees occurring in Old World wet tropical forests. The subclade including Mangifera, Anacardium, Fegimanra, Bouea, Swintonia, and Gluta (Weeks et al. 2014) is characterized by vessel density $\leq 5$ to as low as 1 per $\mathrm{mm}^{2}$ and mainly non-septate fibers and includes taxa with apotracheal-banded parenchyma, a character unusual within the family (Terrazas 1994). Mangifera appears distinct in having narrow to wide apotracheal parenchyma bands and the tendency toward narrowly aliform-winged paratracheal parenchyma (M. foetida Lour., M. sylvatica Roxb., Mangifera spp., InsideWood 2004-onwards; Gupta \& Agarwal 2008 and Harvard slide collection). The genus has rays varying from primarily uniseriate to multiseriate and rarely uniseriate (Terrazas 1994); prismatic crystals occur in most species but were not noted in the fossil. Anacardium, the only New World representative in this clade, lacks banded-apotracheal parenchyma, generally lacks growth rings, and has aliform parenchyma (when present) of the lozenge type (A. occidentale L., InsideWood 2004-onwards).

Of the fossil woods referred to Anacardiaceae, Mangiferoxylon Awasthi (1965 (1966)), and as amended by Guleria (1983 (1984)), shares some key features with the fossil (apotracheal-banded parenchyma) and includes taxa with vessel density $\leq 5$ per $\mathrm{mm}^{2}$ (M. assamicum Prakash \& Tripathi 1969 (1970)). However, paratracheal parenchyma pattern is difficult to assess and some taxa have well-developed aliform-lozenge parenchyma quite distinct from the fossil (M. pakistanicum Ahmed, Khan, Rajput, Khan 1991). Anacardioxylon mangiferoides Ramanujam (1960), named for its similarity to Mangifera, also has aliform-lozenge parenchyma. All this material is from the Tertiary of Central South Asia.

The fossil shows greatest similarity to Anacardiaceae - Anacardioideae clade 4 (Weeks et al. 2014), and in particular Mangifera and related taxa. Since this assessment rests in part on axial parenchyma pattern, which can be variable and is not always clearly described, and given the exclusively Old World occurrence of the genus, we refer our material to Mangifera.

\section{ANACARDIUM L.}

Anacardium incahausi Woodcock, Meyer et Prado, sp. nov. (Fig. 5)

Diagnosis: Wood with indistinct growth rings, diffuse porous. Vessels solitary and in radial multiples of $2-3$, in two diameter classes, more frequent wider vessels 100-150 $\mu \mathrm{m}$, narrow vessels $50-70 \mu \mathrm{m}$, vessel density $\leq 5$ per $\mathrm{mm}^{2}$, perforations simple, intervessel pits alternate crowded, ray-vessel pits with reduced borders to simple and often enlarged. Fibers septate and non-septate. Axial parenchyma scarce. Rays predominantly 2-3-seriate, with procumbent body ray cells and generally one marginal row of square to upright cells. Rays with prismatic crystals and silica bodies. 
Etymology: Named after the ancient volcano that was the source of the Sexi volcanics.

Holotype: S9 (15 cm in diameter). Other material: S7 (small fragment) and 75005 $(9-10 \mathrm{~cm})$.

Type locality: Piedra Chamana Forest Forest main site, Sexi, Peru, associated with the lahar deposits.

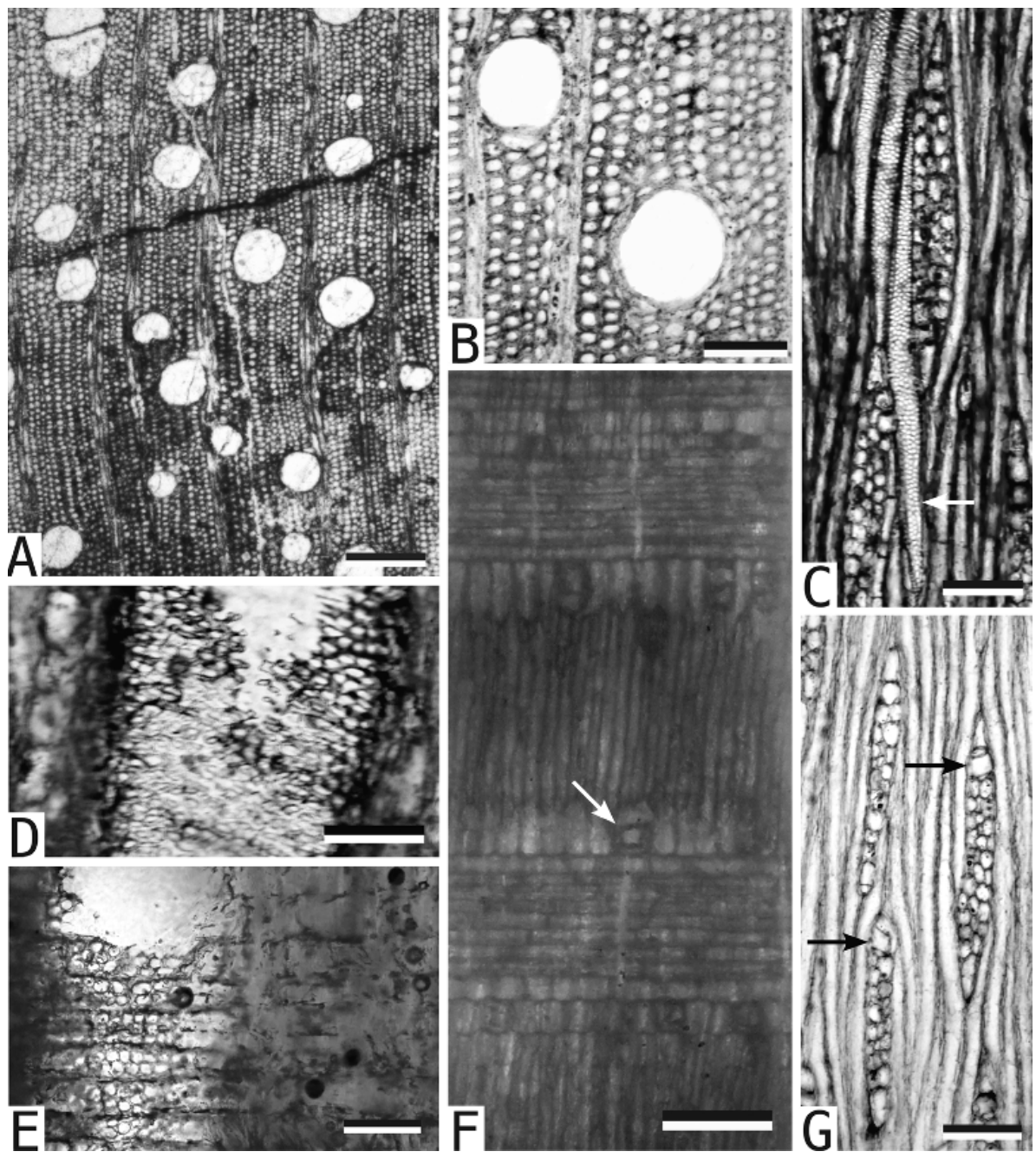

Figure 5. Anacardium incahuasi Woodcock, Meyer et Prado, sp. nov.-A: Diffuse porous wood with sparse, mainly solitary vessels, TS. - B: Fibers thin to medium thick, TS. - C: Vascular tracheids (arrow), TLS. - D: Intervessel pits with oval to slit-like apertures, TLS. - E: Vesselaxial parenchyma pits circular to elongate with reduced borders, silica bodies in procumbent cells, RLS. - F: Rays with one rows of upright to square marginal cells with crystals (arrow), RLS. - G: 2-3-seriate rays with crystals (arrows) in marginal cells, TLS. - Scale bars $=250 \mu \mathrm{m}$ in $\mathrm{A} ; 200 \mu \mathrm{m}$ in $\mathrm{F} ; 100 \mu \mathrm{m}$ in $\mathrm{B}, \mathrm{C}, \mathrm{G} ; 50 \mu \mathrm{m}$ in D, E. 
Description: Growth rings absent or indistinct. Wood diffuse porous (Fig. 5A). Vessels solitary $(\sim 75 \%)$ and in radial multiples of $2-3$, in two diameter classes (Fig. $5 \mathrm{~A}$ ); wider vessels with tangential diameter $131 \pm 18 \mu \mathrm{m}$, less frequent narrow vessels $50-70 \mu \mathrm{m}$ in diameter; vessel density $\sim 5$ per $\mathrm{mm}^{2}$; vessels round in outline, perforations simple, with horizontal to oblique end walls, often with long tails; intervessel pits crowded, alternate, polygonal, with oval to slit-like apertures, $\sim 5-8 \mu \mathrm{m}$ in diameter (Fig. 5D); vessel-ray and vessel-parenchyma pits with reduced borders to simple, similar to intervessel pits in size and shape to enlarged and occasionally elongate (Fig. 5E); vessel element length $411 \pm 157 \mu \mathrm{m}$. Vascular tracheids (Fig. 5C) infrequent. Fibers septate and non-septate, walls very thin to medium thick (Fig. 5B), $\sim 680 \mu \mathrm{m}$ long, tangential lumen diameter $\sim 18 \mu \mathrm{m}$, minutely bordered pits in radial walls. Axial parenchyma paratracheal, scarce; in strands of 3-6 cells. Rays (1-)2-3-seriate (Fig. $5 \mathrm{C}, \mathrm{G})$, body ray cells procumbent with 1 or (less commonly) up to 4-6 marginal rows of square and upright cells (Fig. 5F), some uniseriate rays 1-3 cells high, higher rays occasionally with square or high procumbent cells mixed through body of ray; some rays joined vertically through uniseriate extensions; height $349 \pm 162 \mu \mathrm{m}, \sim 5$ per mm. Large prismatic crystals in marginal ray parenchyma cells that are often somewhat to distinctly enlarged (Fig. 5F,G), generally one per cell but occasionally paired. Spheroidal silica bodies in procumbent ray cells (Fig. 5E).

Affinity. In the InsideWood database, the combination of vessels 100-200 $\mu \mathrm{m}$, rays 1-3-seriate and with 1-4 rows of upright/square marginal cells, prismatic crystals in upright and/or square ray cells, and silica bodies in rays (IAWA characters 42, 97, 106, 107, 137, 160) occurs only in Anacardiaceae (Anacardium, Buchanania, Faguetia, Lannea, Loxopterygium) and Burseraceae (Canarium, Commiphora, Dacryodes, Santiria). Libriform fibers, vessel-ray pits with reduced borders, and prismatic ray crystals are typical of Anacardiaceae; vasicentric tracheids and vessels in two diameter classes also occur within this family (Dong \& Baas 1993; Terrazas 1994). The related Burseraceae are similar to Anacardiaceae (woods generally diffuse porous with enlarged vessel-axial parenchyma pits and heterocellular rays). Although few characters appear to differentiate them consistently (Klaassen 1999; Wheeler \& Manchester 2002), Burseraceae generally have fibers that are all septate. The fossils appear most similar to Anacardium. Vessel density $\leq 5$ per $\mathrm{mm}^{2}$ is consistent with placement in the clade including Anacardium, Fegimanra, Bouea, Mangifera, Swintonia, and Gluta (Weeks et al. 2014). Anacardium, the only New World taxon in this clade, is a genus of $\sim 40$ species of evergreen shrubs to large trees occurring in dry to wet forests, mainly in South America. The genus lacks radial canals, which occur widely within the family, is variable with respect to axial parenchyma (from scanty paratracheal/vasicentric to aliform/aliform-confluent), and includes taxa with septate and non-septate fibers and vessels in two diameter classes (Terrazas 1994). Included taxa also have both crystals and silica bodies in rays, an unusual combination in dicot woods (Terrazas 1994 and personal communication), and vascular tracheids (Richter \& Dalwitz 2000onwards). One difference is that intervessel pits are medium to large rather than small to medium as in the fossils. 
Among fossil woods, Anacardioxylon Felix (1882) is a broadly circumscribed form genus including fossil material, mostly from the Old World (Gregory et al.2009), with general characteristics of anacardiaceous woods (Franco \& Brea 2008). Anacardioxylon caracoli Schönfeld from the Miocene of Colombia, referred to this form genus because of similarities to Anacardium, is similar to the fossil in most characteristics but differs in some quantitative characters (significantly wider vessels at 200-300 $\mu \mathrm{m}$ diameter and larger intervessel pits; Schönfeld 1947).

The fossil shows greatest correspondence to modern Anacardium and is assigned to a newly erected fossil species within this genus.

\section{Apocynaceae}

\section{TABERNAEMONTANA L.}

Tabernaemontana moralesii Woodcock, Meyer et Prado, sp.nov. (Fig. 6)

Diagnosis: Wood with distinct growth rings, diffuse porous. Vessels solitary and in short to long radial multiples, crowded, mean tangential diameter $\sim 50 \mu \mathrm{m}$, perforations simple, intervessel pits crowded alternate, ray-vessel pits similar to intervessel pits. Fibers septate. Axial parenchyma scarce or absent. Rays (1-)2-seriate; uniseriate rays of high upright cells, biseriate rays with procumbent body ray cells and long uniseriate extensions of high-procumbent, square, and/or high upright cells; biseriate portions as wide as uniseriate portions.

Etymology: Named after the geologist Guillermo Morales Serrano, the first scientist to visit the fossil forest at Sexi and who began the work of studying and conserving the site and fossils.

Holotype: S143 (15 cm in diameter). Other material: S123 $(15 \mathrm{~cm})$.

Type locality: Piedra Chamana Fossil Forest main site, Sexi, Peru, associated with the lahar deposits.

Description: Growth rings present, marked by changes in vessel density and fiber diameter and wall thickness, and also areas of narrow, very thick-walled fibers along the ring boundary (Fig. 6B). Wood diffuse porous (Fig. 6A). Vessels crowded, solitary and in short to 8-10(-13) vessel-long radial multiples (Fig. 6A); tangential diameter $54 \pm 10 \mu \mathrm{m}, 184$ per $\mathrm{mm}^{2}$; solitary vessels round to angular in outline, perforations simple, end walls oblique; intervessel pits alternate, crowded, circular to polygonal, $\sim 5 \mu \mathrm{m}$ (Fig. 6C); ray-vessel pits bordered, similar in size and shape to intervessel pits (Fig. 6D); vessel element length $444 \pm 97 \mu \mathrm{m}$. Fibers septate (Fig. 6F), generally medium- to thick-walled, with minutely bordered pits, length $771 \pm 163 \mathrm{~mm}$. Axial parenchyma scarce or absent. Rays 1-2-seriate (Fig. 6E); uniseriate rays of high upright cells, 4 or more cells high; biseriate rays more common, with procumbent body ray cells and uniseriate extensions that are 1-7 cells high and composed of high-procumbent, square, and/or upright cells 6-7 times as high as the body ray cells (Fig. 6E,G); biseriate portions as wide as uniseriate portions (Fig. 6E); $345 \pm 91 \mu \mathrm{m} ; \sim 5$ per mm. Rays often fused vertically by uniseriate extensions.

Affinity. The combination of vessels in radial multiples $\geq 4$ and with simple perforations, vessel ray pits bordered and similar to intervessel pits, septate fibers, and rays 1-3-seriate with multiseriate portions as wide as uniseriate portions and 4-12 per $\mathrm{mm}$ 


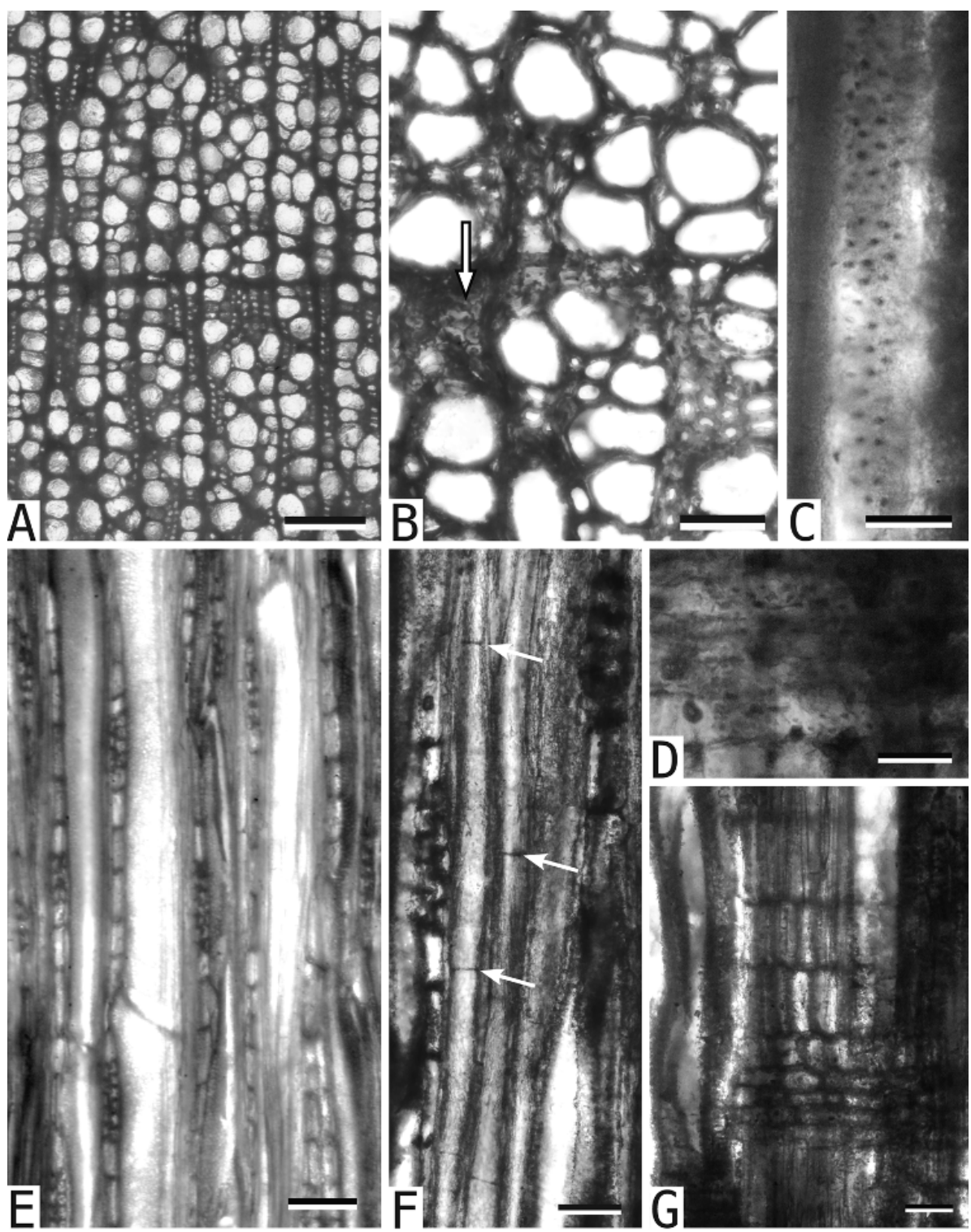

Figure 6. Tabernaemontana moralesii Woodcock, Meyer et Prado, sp.nov. - A: Vessels in radial multiples, TS . - B: Thick-walled fibers along the growth ring boundary (arrow), TS. - C: Alternate intervessel pits, TLS. - D: Bordered ray-vessel pits, RLS. - E: Rays with biseriate portions as wide as uniseriate portions and long uniseriate extension, TLS. - F: Fibers with septae (arrows), TLS. - G: Rays with extensive margins of upright cells, RLS. - Scale bars $=200 \mu \mathrm{m}$ in $\mathrm{A}, \mathrm{E} ; 75 \mu \mathrm{m}$ in $\mathrm{B} ; 40 \mu \mathrm{m}$ in $\mathrm{F}, \mathrm{G} ; 20 \mu \mathrm{m}$ in $\mathrm{C}, \mathrm{D}$. 
(IAWA characters 10,13,30, 65, 97, 100,115) occurs only in Anartia/Tabernaemontana (Apocynaceae - Tabernaemontaneae) and Guettarda (Rubiaceae) in the InsideWood database. Small intervessel pits, vessel-ray pits similar to intervessel pits, unseriate rays of square to upright cells, and multiseriate rays with 1-4 rows of upright cells are characteristic of Apocynaceae. Vessels in radial multiples, septate fibers, axial parenchyma scarce to absent, and rays more commonly multiseriate than uniseriate characterizes Tabernaemontaneae within the family (Lens et al. 2008). Rays with multiseriate portions as wide as uniseriate portions appears to be a consistent feature of Tabernaemontana, which includes taxa (such as T. catharinensis A.DC.) with very densely arranged vessels similar to the fossil material. This genus of understory shrubs and small trees ( $>100$ species) has a pantropical distribution in mesic lowland forests. Guettarda (Rubiaceae) also includes species (G. elliptica Sw.) very similar to the fossil. Shared characters apparent in Guettarda are rays frequently fused by uniseriate extensions and multiseriate rays more common than uniseriate ones; differences are the occurrence of uniseriate rays 2 cells high, rays generally not with multiseriate portions as wide as uniseriate portions (G. elliptica an exception), and vessels less dense than in the fossil.

Of the two fossil taxa of Apocynaceae included in InsideWood, Apocynoxylon sylvestris Gazeau \& Koeniguer differs from the fossil in having banded parenchyma and Aspidospermoxylon uniseriatum Krause in having solitary vessels and radial canals. Information regarding Tabernaemontana sp. from the Pliocene of Africa (Dechamps 1983, cited in Gregory et al. 2009) could not be consulted.

The fossil shows closest correspondence to Tabernaemontana in the Apocynaceae and is therefore assigned to a newly erected fossil species within this genus.

\section{Combretaceae}

\section{Combretaceae cf. Thiloa (Fig. 7)}

Growth rings apparently present but incomplete, marked by fibers along boundary or changes in cell dimensions. Wood diffuse porous (Fig. 7A). Vessels mostly solitary, in two diameter classes (Fig. 7A), tangential diameter of wide vessels $220 \pm 62 \mu \mathrm{m}$, $\sim 8$ per $\mathrm{mm}^{2}$; additional very narrow vessels also occasionally present, sometimes in radial arrangement (Fig. 7B), with tangential diameter $30 \pm 12 \mu \mathrm{m}$; vessels round to oval in outline, perforations simple, end walls transverse; intervascular pits crowded, alternate, 4-5 $\mu \mathrm{m}$ (Fig 7F); vessel-ray and vessel-axial element pits bordered, similar to intervessel pits but smaller $(2-3 \mu \mathrm{m})$; wide vessel elements $482 \pm 93 \mu \mathrm{m}$ long, length approximating that of the narrow vessel elements and vascular tracheids. Ground tissue made up of axial parenchyma, narrow vessels, vascular tracheids and thin-walled fibers. Small to large radially oriented perforations occurring in narrow vessels and vascular tracheids (Fig. 7I,J) and appearing aligned with perforations in radial walls of ray cells. Fibers including thin-walled septate fibers of the ground tissue and narrow, very thick-walled fibers (Fig. 7C) occurring irregularly and in patches/short bands along apparent growth ring boundaries. Axial parenchyma scanty paratracheal and apotracheal, often appearing to intergrade with septate fibers; in strands of 2-8 cells. Rays 1-3(-4)-seriate (Fig. 7H), composed of procumbent cells, less commonly with one row of marginal square to upright cells (Fig. 7E) or square and procumbent cells 


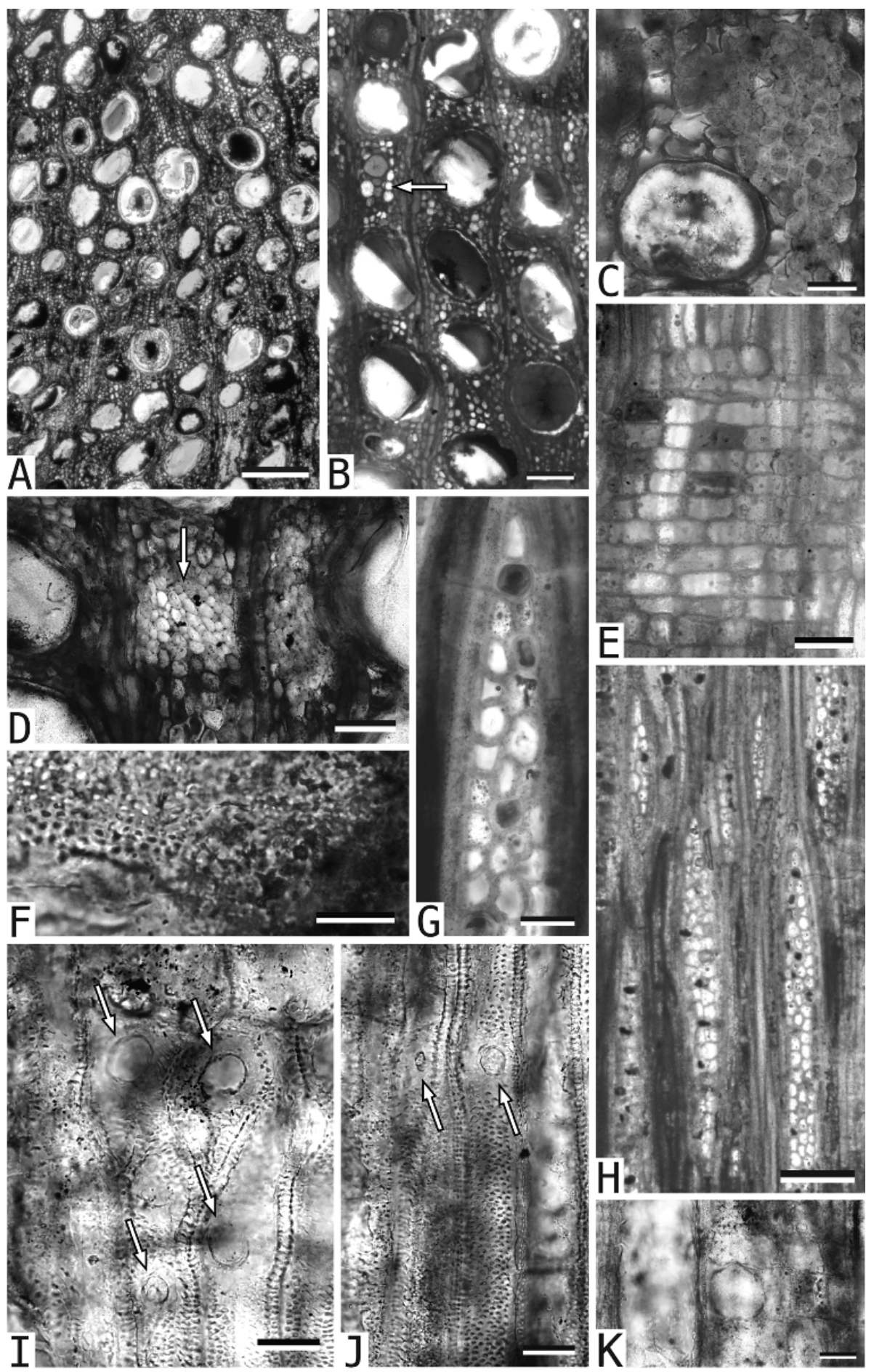


occurring throughout, cells often appearing thick-walled (Fig. 7G); uniseriate rays 1-7 cells high, multiseriate ray height $825 \pm 347 \mu \mathrm{m}$; highest rays $>1 \mathrm{~mm}$; frequency $\sim 4$ per mm. Rays with small to large perforations in radial (Fig. 7K) and tangential walls; radial perforations appearing aligned with perforations in narrow vessels and axial elements that otherwise appear to be vascular tracheids. Included phloem in irregularly arranged strands, $\sim 150-400 \times \sim 300-500 \mu \mathrm{m}$ (radial $\times$ tangential dimensions) (Fig. 7D). Dark material in vessels and ray cells (Fig. 7B,G).

Specimen: $\mathrm{S} 104$ (3.5 cm in diameter).

Affinity. In the InsideWood database, the combination of vessels not arranged in long radial multiples or clustered, with ray-vessel pits similar to intervessel pits and not with reduced borders, vascular tracheids, non-septate fibers, larger rays not $>10$-seriate, and diffuse included phloem (IAWA characters 30, 60, 66, 134, with 10, 11, 31, 32 and 99 absent) occurs only in Calophyllaceae (Lebrunia), Combretaceae (Combretum, Getonia, Thiloa), Loganiaceae (Strychnos), and Thymelaeaceae (Dirca). The fossil is most similar to woods in Combretaceae - Combretinae. Characters consistent with placement in this family include vessels with simple perforations, alternate intervessel pits, chambered parenchyma (although generally with crystals), rays 1-3-seriate and weakly heterocellular (with infrequent upright marginal cells), and vascular tracheids as ground tissue in taxa with solitary vessels (Van Vliet 1979; Van Vliet \& Baas 1984). Phloem strands appear similar to those described for Combretaceae, which have included rays (Den Outer \& Van Veenendaal 1995; Rajput et al. 2009). Minute intervessel pits are uncommon in Combretaceae but some taxa (Combretum nigricans Leprieur ex Guill. \& Perr., C. aculeatum Vent., Strephonema) have minute to small pits (InsideWood 2004-onwards). Most taxa in Combretaceae have rays that are exclusively or predominantly uniseriate and lower than in the fossil. Combretinae is distinguished by narrow vessels associated with wider vessels and often in radial multiples and the occurrence of taxa with included phloem (Van Vliet 1979; Van Vliet \& Baas 1984). The perforations in ray cells appear to correspond to the radial vessels described as occurring in all Combretinae (Van Vliet \& Baas 1984). These conduits run radially through perforations in tangential walls of ray cells and connect to vessels or vascular tracheids through perforations in radial walls (Van Vliet 1976; Van Vliet \& Baas 1984). The fossil exhibits features (wide vessels in two diameter classes, abundant parenchyma, vascular tracheids, included phloem) typical of lianas (Carlquist 1988), which are restricted to Combretinae within Combretaceae. Vessel diameter and density and vessel-element length correspond to that of lianas in this group (Van Vliet 1979). The fossil is most similar to Thiloa, Getonia, and Guiera, basal lineages within Com-

Figure 7. Combretaceae cf. Thiloa. - A: Wide, densely packed vessels in 2 diameter classes, TS. - B: Narrow vessels in radial multiples (arrow), TS. - C: Very thick-walled fibers, TS. D: Phloem strand (arrow), TS. - E: Ray with one row of marginal upright cells, RLS. - F: Minute to small pits in end of vessel element, TLS. - G: Ray with thick-walled cells, TLS. - H: 1-3seriate rays, TLS. - I \& J: Vascular tracheids with perforations in radial walls (arrows), RLS. K: Perforated ray cell, RLS. - Scale bars $=500 \mu \mathrm{m}$ in A; $200 \mu \mathrm{m}$ in B, H; $100 \mu \mathrm{m}$ in A, D; $50 \mu \mathrm{m}$ in $\mathrm{C}, \mathrm{G}, \mathrm{I} ; 25 \mu \mathrm{m}$ in $\mathrm{K}, \mathrm{J} ; 20 \mu \mathrm{m}$ in $\mathrm{F}$. 
bretinae (Maurin et al.2010). Thiloa, the only New World example, is a genus of lianas occurring in South American lowland forests. The character of rays with thick-walled cells is mentioned as unique to Thiloa within Combretinae (Van Vliet 1979). Of the seven included species, the only one available for comparison (T. glaucocarpa Eichler; InsideWood 2004-onwards) differs from the fossil in having exclusively uniseriate rays and much narrower, more densely arranged vessels. New World species of Combretum ( 40) are lianas or scandent shrubs and are not well represented in available databases. Combretum laxum Jacq. (Aw), the only New World taxon for which information is available, is similar to the fossil in having rays that are high and 1-3(-4)-seriate with wider rays predominating but lacks fibers in bands/patches and included phloem. It is notable that included phloem in Combretum is generally absent from lianas and occurs only in (African) tree taxa (Van Vliet \& Baas 1984).

Although fossil woods referred to Combretaceae in InsideWood (2004-onwards) share some features with the fossil specimen, none has included phloem or other features characteristic of a liana. However, a fossil wood from the Clarno Nut Bed (Xylotype III-A-1, Wheeler \& Manchester 2002), with vine-like anatomy and likely affinity with Myrtalean families Combretaceae or Melastomataceae, is anatomically very similar to the fossil. Shared characters include intervessel pits minute to small and areas of (nonpreserved) unlignified tissue occurring in irregular short bands and interpreted as possible areas of included phloem. The most significant differences are wider (6-9 cell wide) multiseriate rays and absence of perforations or radial vessels.

The wood shows distinct similarity to Thiloa within Combretaceae-Combretinae but also exhibits some differences from the one species for which information is available and is referred to the genus.

\section{Cordiaceae ( Boraginaceae)}

\section{CORDIA L.}

The three wood types that have been placed in Cordia differ in features relating to vessel diameter and grouping, ray width and height, and occurrence of crystals. These differences are summarized in Table 1. Cordia asenjoi also has a distinctive vessel diameter distribution and $C$. florifera what appear to be bud gaps, possibly associated with floral axes, embedded in the wood.

Table 1. Comparison of the Piedra Chamana Cordia wood types.

$\mathrm{VD}=$ diameter of widest/earlywood vessels, $\mathrm{Rad}$ pairs = vessels in radial pairs, Tang groups = vessels in tangential groups, $\mathrm{RW}=$ ray width in cell numbers, $\mathrm{RH}=$ ray height.

\begin{tabular}{lcccccc}
\hline & VD & $\begin{array}{c}\text { Rad } \\
\text { pairs }\end{array}$ & $\begin{array}{c}\text { Tang } \\
\text { groups }\end{array}$ & RW & RH & Crystals \\
\hline C. asenjoi & $175-200 \mu \mathrm{m}$ & + & little evident & $1-5$ & $\sim 1 \mathrm{~mm}$ & rare \\
C. eocenensis & $\sim 170 \mu \mathrm{m}$ & - & + & $3-5$ & $\sim 1 \mathrm{~mm}$ & $\begin{array}{c}\text { crystals in } \\
\text { rays }\end{array}$ \\
C.florifera & $95-135 \mu \mathrm{m}$ & - & + & $1-3$ & $\sim 300 \mu \mathrm{m}$ & $\begin{array}{c}\text { crystal sand } \\
\text { in rays }\end{array}$ \\
\hline
\end{tabular}


Cordia asenjoi Woodcock, Meyer et Prado, sp. nov. (Fig. 8)

Diagnosis: Wood with distinct growth rings, semi-ring porous. Vessels solitary, in radial pairs, and in tangential pairs or groupings; earlywood vessel diameter 100-200 $\mu \mathrm{m}$, perforations simple, intervessel pits alternate. Fibers non-septate. Parenchyma scanty paratracheal to aliform-lozenge or confluent and marginal. Rays non-storied,

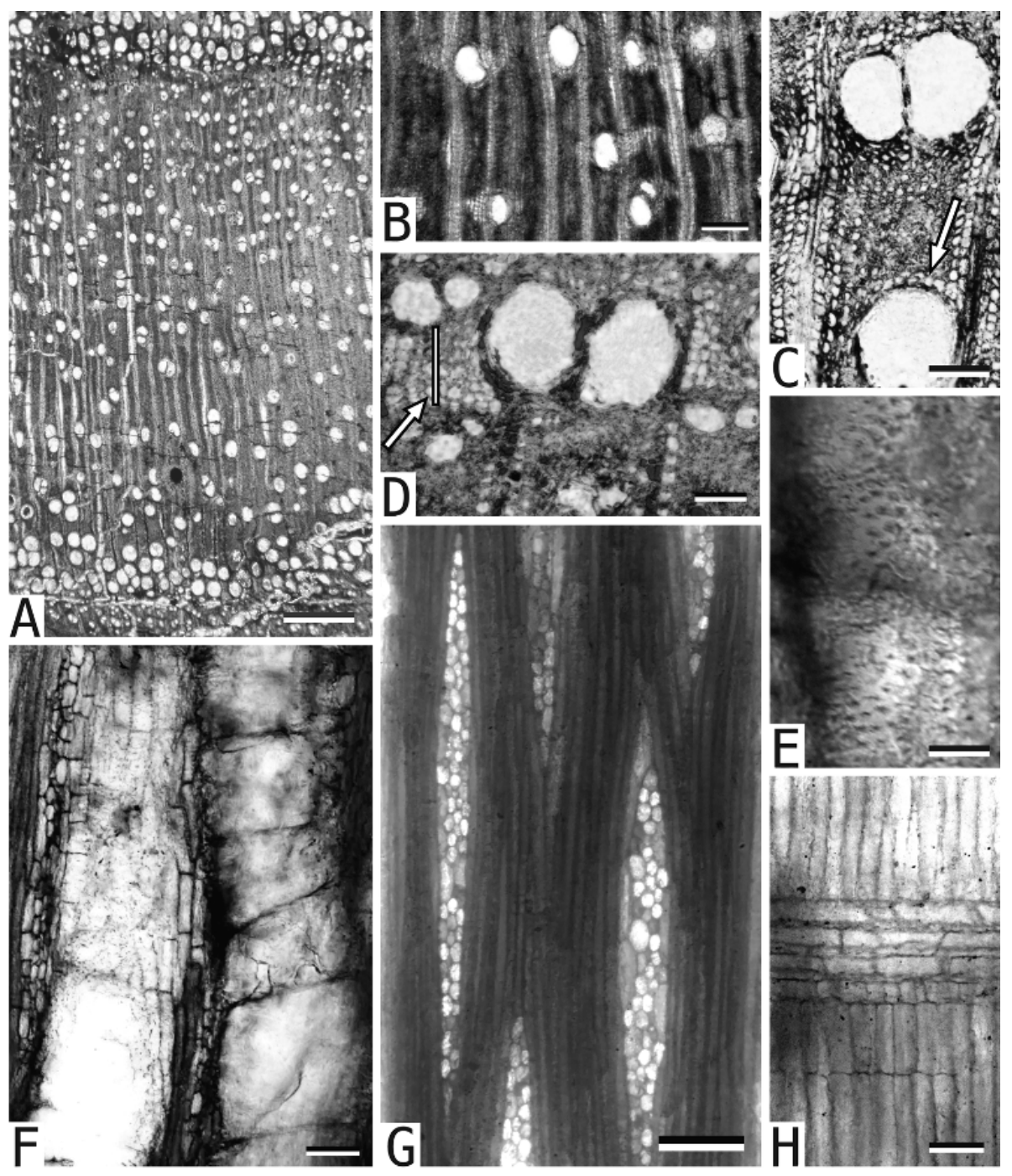

Figure 8. Cordia asenjoi Woodcock, Meyer et Prado, sp.nov. - A: Wood semi-ring porous, TS. - B: Aliform-confluent parenchyma, TS. - C: Scanty paratracheal parenchyma (arrow), TS. D: Marginal parenchyma (bracket), very thick-walled fibers, TS. - E: Intervessel pits small, alternate, TLS. - F: Short vessel elements, TLS. - G: Rays with sheath cells, TLS. - H: Ray with procumbent cells of varying heights and high upright cells, RLS. - Scale bars $=1 \mathrm{~mm}$ in $\mathrm{A} ; 200 \mu \mathrm{m}$ in $\mathrm{B} ; 100 \mu \mathrm{m}$ in $\mathrm{C}, \mathrm{H} ; 75 \mu \mathrm{m}$ in $\mathrm{D}, \mathrm{F}, \mathrm{G} ; 25 \mu \mathrm{m}$ in $\mathrm{E}$. 
1-5-seriate, composed of procumbent cells or with 1 to 2 rows of marginal square to upright cells, with sheath cells, some rays $>1 \mathrm{~mm}$ in height.

Etymology: Named for Santiago Asenjo Davila, in recognition of his support of the scientific work in Sexi.

Holotype: 75015 (20 cm in diameter).

Type locality: Piedra Chamana Fossil Forest main site, Sexi, Peru, associated with the lahar deposits.

Description: Growth rings distinct, marked by changes in vessel size and density and fiber wall thickness and marginal parenchyma (Fig. 8A,D). Wood semi-ring porous (Fig. 8A). Vessels solitary, in radial to tangential pairs and occasional small tangential groups (Fig, 8A); earlywood vessel diameter 100-200 $\mu \mathrm{m}$, latewood vessel diameter 50-75 $\mu \mathrm{m}$ (distribution including the following modal diameter categories: 175-200 $\mu \mathrm{m}$ diameter earlywood vessels, 100-125 $\mu \mathrm{m}$ diameter vessels distributed over most of the ring, and 50-75 $\mu \mathrm{m}$ diameter latewood vessels); vessels round to oval in outline, perforations simple; intervessel pits alternate, round to oval, $5-8 \mu \mathrm{m}$ (Fig. 8E); ray-vessel pits not clearly observed; vessel elements short (Fig. 8F), length $201 \pm 58$ $\mu \mathrm{m}$. Fibers non-septate, thin- to very thick-walled, fiber pitting not observed. Axial parenchyma scanty paratracheal (Fig. 8C) to irregularly lozenge aliform or confluent (Fig. 8B), also marginal in bands 5-6 cells wide (Fig. 8D); in strands of 2-4 cells. Rays 1-5-seriate (Fig. 8G), composed of procumbent cells or with one (to two) marginal row(s) of square to upright cells (Fig. 8H) often partly ensheathing the ray (Fig. 8G); procumbent cells of varying heights; marginal and sheath cells frequently very high; ray height $925 \pm 348 \mu \mathrm{m}$, frequency $\sim 4$ per mm. Prismatic crystals in upright ray parenchyma cells (infrequently observed).

Affinity. In the IAWA database, the combination of semi-ring porous wood, vessels with small intervessel pits and 100-200 $\mu$ m diameter, very thick-walled fibers, axial parenchyma in strands of $2-4$, and rays with sheath cells and $\leq 4$ per $\mathrm{mm}^{2}$ (IAWA characters 4, 25, 42, 70, 91, 92, 110, 114) occurs in Cordia alliodora (Ruiz \& Pavon) Oken and $C$. hintonii Johnst. of the Cordiaceae. Wood tending toward semi-/ring porosity, vessels in clusters and tangential bands, round intervessel pits, and rays with sheath cells (Gottwald 1983; Gottschling et al. 2016), along with short to very short vessel elements (Barajas-Morales 1981) - characters shared with the other two Cordia wood types - are consistent with placement in the Cordiaceae. This fossil specimen has the additional characters of non-septate fibers and rays with crystals, which are also consistent with this placement. Coalescent pit apertures have been described in some species (Barajas-Morales 1981; Gottwald 1983). Cordia is a large genus ( 300 species) of shrubs and small to large trees with a tropical to subtropical distribution that is most diverse in seasonally dry areas of the New World tropics (Gottschling et al. 2005). The fossil shares the most coded characters with the New World taxa $C$. alliodora, C. hintonii, and C. sonorae Rose. Cordia alliodora may be most similar to the fossil and has similar vessel arrangement and cell dimensions. This widespread species is variable in paratracheal parenchyma arrangement and ray width and number of marginal rows (Barajas-Morales 1981; Richter \& Dallwitz 2000-onwards; León 2003). Cordia sonorae differs in vessel patterning and has less frequent rays. These two taxa have been placed 
in section Gerascanthus (now part of the Sebestena subclade of Cordia; Gottschling et al. 2005), which has been considered distinguishable from other Cordiaceae by very thick-walled fibers and prismatic crystals in ray parenchyma (Gottwald 1983). Cordia hintonii (Collococcus subclade) is also similar but has banded parenchyma.

Among fossil woods, Cordioxylon Awasthi (1984), including Cordioxylon prototrichotomia Brea \& Zucol (2006) from the Paleocene of Patagonia, differs from this and the other two Cordia wood types in lacking growth ring boundaries and being diffuse porous.

The wood shows greatest similarity to New World species of Cordia, particularly C.alliodora, and is assigned to a newly erected fossil species within this genus.

\section{Cordia eocenica Woodcock, Meyer et Prado, sp. nov. (Fig. 9)}

Diagnosis: Wood with distinct growth rings, semi-ring porous. Vessels solitary and in irregular, often tangential groupings, earlywood tangential diameter 150-200 $\mu \mathrm{m}$, perforations simple, intervessel pits alternate, vessel-axial parenchyma pits similar to intervessel pits. Fibers non-septate. Parenchyma scanty paratracheal to vasicentric and confluent, also in marginal bands. Rays 3-5-seriate, with procumbent body cells, one row of upright to square cells, and sheath cells, ray height $>1 \mathrm{~mm}$. Prismatic crystals in rays.

Etymology: Named after the age of the fossil assemblage.

Holotype: S156 $(10 \mathrm{~cm}$ in diameter). Other material: S62 $(8 \times 9 \mathrm{~cm}), \mathrm{S} 69(10 \times 13$ $\mathrm{cm}), \mathrm{S} 77(16 \mathrm{~cm}), \mathrm{S} 78$ (fragment).

Type locality: Piedra Chamana Fossil Forest main site, Sexi, Peru, associated with the lahar deposits.

Description: Growth rings present, marked by differences in vessel diameter and density and marginal parenchyma (Fig. 9A,B). Wood semi-ring porous (Fig. 9A). Vessels solitary, paired tangentially, and in irregular, sometimes tangential groupings (Fig. 9A); earlywood tangential vessel diameter $\sim 170 \mu \mathrm{m}$, latewood vessel diameter $\sim 60-100 \mu \mathrm{m}$; vessels round to slightly angular in outline, perforations simple; intervessel pits alternate, circular, apertures slit-like to elongate and coalescent, 4-7 $\mu \mathrm{m}$ (Fig. 9E); vessel-axial parenchyma (and vessel-ray?) pits bordered, similar to intervessel pits; vessel elements very short $(137 \pm 38 \mu \mathrm{m})$ (Fig. 9C). Vascular tracheids associated with narrow vessels (Fig. 9F). Fibers non-septate, thin- to thick-walled. Axial parenchyma paratracheal scanty to vasicentric and irregularly confluent near narrow vessels (Fig. 9D); also in marginal bands $\sim 4-10$ cells wide (Fig. 9B); in strands of 2-4(-5) cells (Fig, 9F). Rays 3-5-seriate (Fig. 9G), with procumbent body ray cells and generally one row of upright cells at the margins; procumbent cells of varying heights; sheath cells present (Fig. 9G); ray height $1120 \pm 573 \mu \mathrm{m}$, frequency $3-4$ per mm. Rays often fused vertically. Vessels with dark contents (Fig. 9G). Rays with what appears to be crystal sand (Fig. 9 I); prismatic crystals in upright and high procumbent ray cells (Fig. 9H).

Affinity. In the InsideWood database, the combination of growth rings, small intervessel pits, axial parenchyma confluent and in strands 2-4 cells long, rays with sheath cells and $<4$ per $\mathrm{mm}$, and larger rays $4-10$-seriate (IAWA characters $1,25,83,91,92$, 


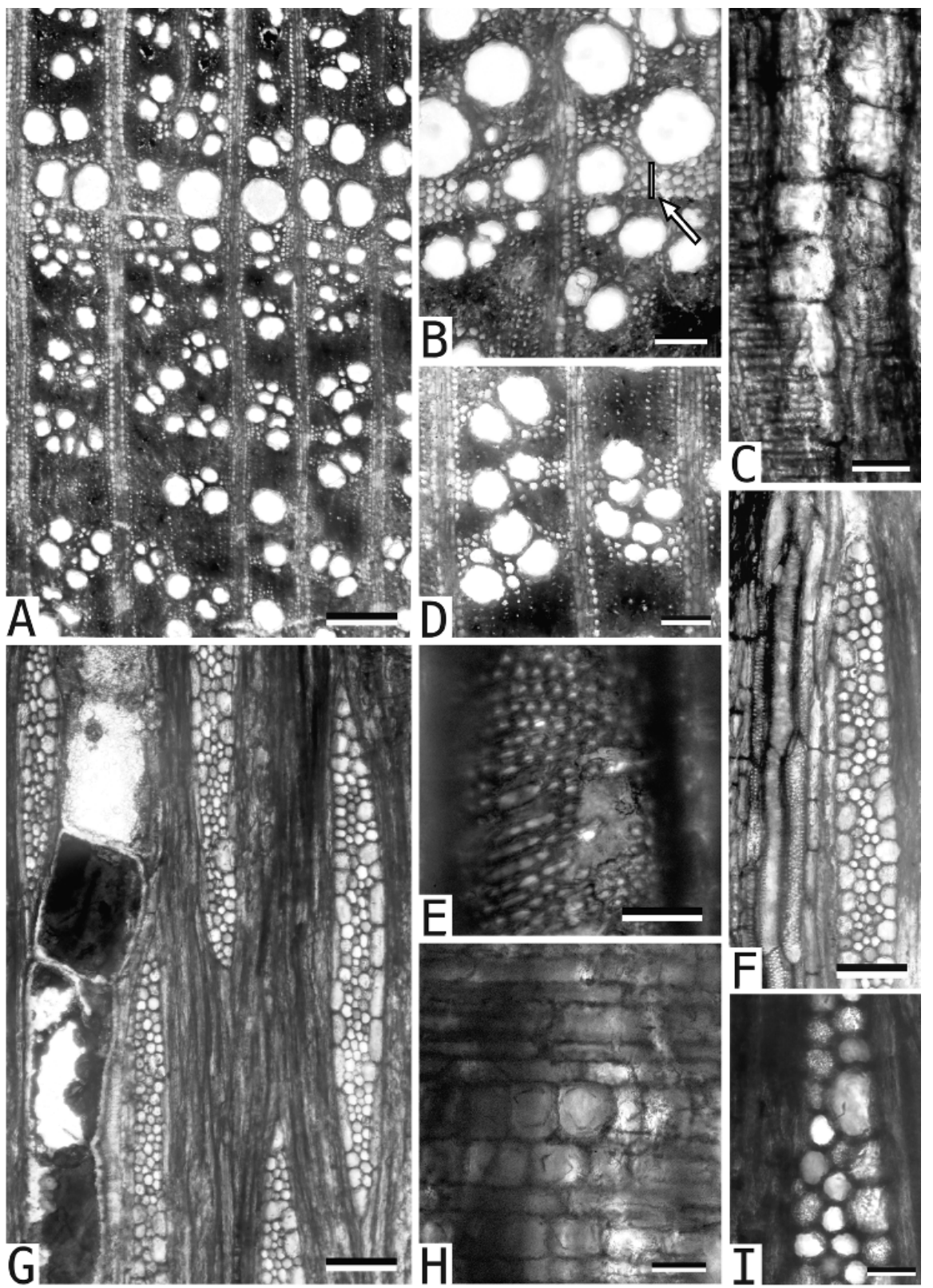

Figure 9. Cordia eocenica Woodcock, Meyer et Prado, sp. nov. - A: Semi-ring porous wood, tangential vessel clusters, TS. - B: Marginal parenchyma (arrow), TS. - C: Short vessel elements, RLS. - D: Vessel clusters with confluent parenchyma, TS. - E: Intervessel pits with apertures elongate to coalescent, RLS. - F: Vascular tracheids intergrading with narrow vessel elements, axial parenchyma strands of 2-4, TLS. - G: Rays with sheath cells, dark contents in vessels, TLS. - H: Ray cells with prismatic crystals, RLS. - I: Ray with crystal sand, TLS. - Scale bars $=250 \mu \mathrm{m}$ in A; $100 \mu \mathrm{m}$ in $\mathrm{B}, \mathrm{C}, \mathrm{D}, \mathrm{F}, \mathrm{G} ; 40 \mu \mathrm{m}$ in $\mathrm{H} ; 25 \mu \mathrm{m}$ in $\mathrm{E}, \mathrm{I}$. 
$110,114,98)$ occurs only in Cordia. In addition to characters shared with the other woods types cited above, vessel-ray pits similar to intervessel pits, septate fibers, and crystals in rays also suggest affinity with Cordiaceae. Coalescent pit apertures also occur in the family (Barajas-Morales 1981; Gottwald 1983). The woods sharing the most coded characters with the fossil are Cordia oncocalyx Allemão (within which Auxemma glazioviana Taub. and A. oncocalyx Allemão are now subsumed), Cordia goeldiana Uber, and $C$. sonorae Rose in the Sebestena subclade of the genus (Gottschling et al. 2005). Although crystal sand is common in Boraginaceae/Boraginales, prismatic crystals are considered synapomorphic for the Sebestena subclade (Heubl et al. 1990; Gottschling et al. 2005). Cordia oncocalyx, the species most similar to the fossil, has shared characters including vessel arrangement (earlywood vessels tangentially paired rather than in radial multiples, latewood vessels in tangential clusters), reddish-brown substances in vessels, prismatic crystals, and apparent marginal parenchyma but has fibers both septate and non-septate (Gottwald 1983). Cordia goeldiana and C. sonorae have a different vessel-distribution pattern (vessels mostly solitary and not clustered), but are similar to the fossil in most other characters. Closely related Cordia americana (L.) Gottschling \& J.S.Mill. also has tangential vessel groupings but differs in having less distinctly ring porous wood, vessels narrower and including radial multiples, minute pits, and higher ray density (Gottwald 1983; Richter \& Dallwitz 2000-onwards).

The wood shows the greatest similarity to the Sebestena clade of Cordia, particularly Cordia oncocalyx, and is assigned to a newly erected fossil species within this genus.

Cordia florifera Woodcock, Meyer et Prado, sp. nov. (Fig. 10)

Diagnosis: Wood with distinct growth rings, semi-ring porous. Vessels solitary and in small clusters, latewood vessels tangentially grouped or arranged, perforations simple, tangential diameter generally 50-100 $\mu \mathrm{m}$, intervessel pits crowded alternate, vessel-ray pits similar to intervessel pits. Fibers non-septate or with thin septae. Axial parenchyma scanty paratracheal to vasicentric and linking latewood vessels in confluent bands. Rays 1-3-seriate, multiseriate rays with procumbent body cells and often 1-2 rows of marginal square cells and sheath cells and incorporating fibers and axial parenchyma. Structures present in the wood apparently representing bud gaps associated with floral axes.

Etymology: This wood is named after its presumed cauliflorous habit.

Holotype: S59 (5 cm in diameter). Other material: S11 $(13 \mathrm{~cm})$.

Type locality: Piedra Chamana Fossil Forest main site, Sexi, Peru, associated with the lahar deposits.

Description: Growth rings marked by changes in vessel diameter and density and marginal parenchyma, the widest vessels not always at the ring boundary (Fig. 10A). Wood semi-ring porous (Fig. 10A). Vessels solitary, in radial pairs and in small clusters of 2-3(-4) (Fig. 10A); latewood vessels tangentially grouped or arranged, perforations simple; mean tangential diameter $54 \pm 15 \mu \mathrm{m}$ (diameter distribution with a modal range of 45-60 $\mu \mathrm{m}$ and an outlier of wider vessels 90-135 $\mu \mathrm{m}$ ); vessels round in outline; 


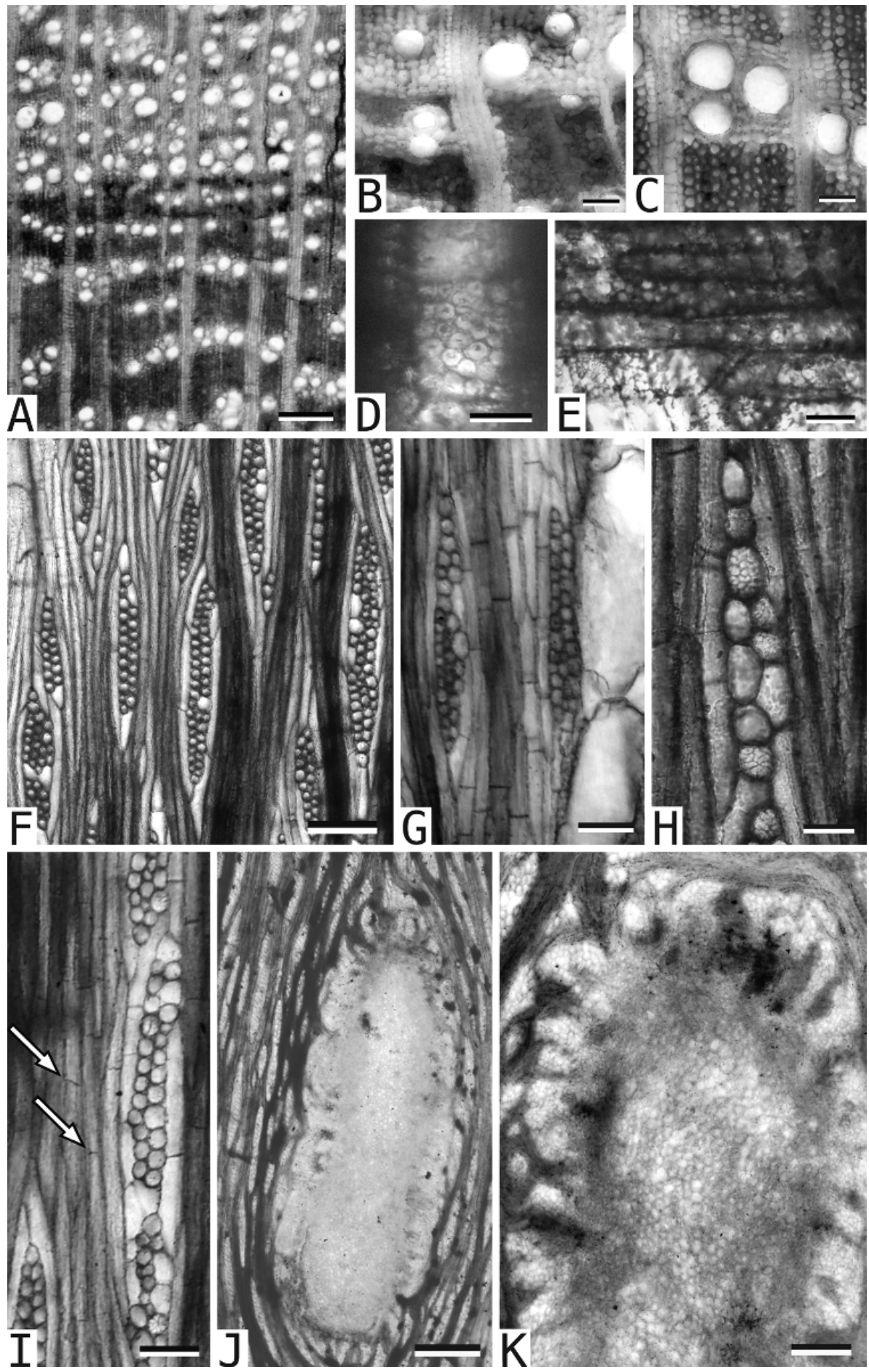


intervessel pits crowded, alternate, round to polygonal, with small, round to slit-like apertures, (3-4) 5-6 um (Fig. 10D); vessel-ray and vessel-axial parenchyma pits similar in size and shape to intervessel pits (Fig. 10E); vessel element length $174 \pm 39 \mu \mathrm{m}$. Fibers non-septate or with thin septae (Fig. 10I), very thin- to very thick-walled, minutely bordered pits in tangential and radial walls, length $295 \pm 86 \mu \mathrm{m}$. Axial parenchyma scanty paratracheal to vasicentric, confluent-banded in short bands linking latewood vessels (Fig. 10C), and marginal in bands 2-7 cells wide (Fig. 10B); in strands of 2-4 cells (Fig, 10G). Rays 1-3(-4)-seriate (Fig, 10F); uniseriate rays (1-)2-7 cells high; multiseriate rays more common, composed of procumbent cells, often with 1 to 2 rows of upright marginal cells and sheath cells or incorporating fibers or axial parenchyma (Fig. 10F,I); height $271 \pm 106 \mu \mathrm{m}$, frequency $\sim 6$ per mm. Tyloses in vessels (Fig. 10G). Crystal sand in ray parenchyma (Fig. 10H). Two large parenchymatous structures $\sim 0.5 \mathrm{~mm}$ wide present in tangential longitudinal section (Fig. 10 J,K), appearing to be obliquely sectioned bud gaps with smaller bud gaps at the periphery possibly associated with floral axes.

Affinity. In the InsideWood database, the combination of vessels 50-100 $\mu \mathrm{m}$ diameter and in tangential bands, axial parenchyma confluent and marginal, and rays with sheath cells (IAWA characters 6, 41, 83, 89, 110) occurs only in Cordia americana (L.) Gottschling \& J.S. Mill. (formerly Patagonula americana L.). In addition to characters shared with the other two wood types (cited above), vessels with tyloses and fibers with minutely bordered pits also suggest affinity with Cordiaceae (Gottwald 1983). Bud gaps, which are largely parenchymatous breaks in the continuity of the vasculature, can persist in secondary xylem in the case of epicormic or cauliflorous budding; in Cercis L. (Fabaceae), for example, the large bud gaps in the wood are linked to its being cauliflorous (Caringella et al. 2014). The complexity of the structures seen here, which have numerous smaller gaps around the periphery, suggests a bud gap associated with a floral axis rather than an epicormic bud. Although rare within Cordiaceae, cauliflory does occur within Cordia (C. nodosa Lam.) and is prevalent in the lower stratum of tropical forests. Non-cauliflorous $C$. americana is, however, most similar to the fossil; this species has rays that are low relative to related taxa (most Cordiaceae have rays $>500 \mu \mathrm{m}$ in height) and elongate cells or axial parenchyma in a sheathing position and often extending across the ray or connecting rays vertically (Richter \& Dallwitz 2000-onwards; InsideWood 2004-onwards). Ulmiform vessel arrangement, minute intervessel pits, and crystal sand in ray cells and fibers are considered to distinguish

Figure 10. Cordia florifera Woodcock, Meyer et Prado, sp. nov. - A: Wood semi-ring porous with tangentially grouped latewood vessels, TS. - B: Marginal parenchyma, TS . - C: Confluent parenchyma, TS. - D: Polygonal intervessel pits, TLS. - E: Rays with procumbent cells, vessel-axial pits similar to intervessel pits, RLS. - F: Rays 1-4-seriate with sheath cells, TLS. G: Vessel with tyloses, axial parenchyma in strands of 2-3, TLS. - H: Ray with crystal sand, TLS. - I: Rays with sheath cells and incorporated fibers or axial parenchyma, fibers with septae (arrow), TLS. - J \& K: Probable bud gaps, TLS. - Scale bars $=250 \mu \mathrm{m}$ in J; $200 \mu \mathrm{m}$ in A; $100 \mu \mathrm{m}$ in $\mathrm{F}, \mathrm{K} ; 50 \mu \mathrm{m}$ in $\mathrm{B}, \mathrm{C}, \mathrm{G}, \mathrm{I} ; 25 \mu \mathrm{m}$ in $\mathrm{H} ; 20 \mu \mathrm{m}$ in $\mathrm{D}, \mathrm{E}$. 
C. americana from other Cordiaceae (Gottwald 1983). Prismatic crystals, considered a synapomorphy for the Sebestena clade of Cordia but described variously as present or absent in C. americana (Gottwald 1983; Heubl et al. 1990; Richter \& Dallwitz 2000-onwards), were not seen in the fossil. Cordia americana has been described variously as having septate and non-septate fibers (Gottwald 1983). In the case of the first two wood types appearing similar to Cordia, vessel diameter is within the general range seen in the genus; narrow vessels, as seen in this wood type, appear restricted to species that are small trees or shrubs.

The wood shows greatest similarity to the Sebestena clade of Cordia, particularly C. americana, and is assigned to a newly erected fossil species within this genus.

\section{Dipterocarpaceae}

\section{Dipterocarpaceae cf. Pseudomonotes (Fig. 11)}

Growth rings marked by regions of radially flattened fibers with sparse vessels (Fig. 11B). Wood diffuse porous (Fig. 11A). Vessels exclusively solitary, tangential diameter $37 \pm 6.5 \mu \mathrm{m}$, frequency 280 per $\mathrm{mm}^{2}$; vessels round in outline, frequently with long tails (Fig. $11 \mathrm{G}, \mathrm{H}$ ); perforations simple; vessel-fiber pits alternate, round to oval with circular apertures (Fig. 11D), uncrowded except in vessel element tails (Fig. $11 \mathrm{H}), 4-5 \mu \mathrm{m}$; vessel-ray pits bordered, similar to vessel-fiber pits but smaller (2-4 $\mu \mathrm{m})$ (Fig. $11 \mathrm{I}$ ); vessel element length $303 \pm 100 \mu \mathrm{m}$. Fibers non-septate, thick- to very thick-walled (Fig. 11C), varying in width; pits bordered and $\sim 2.5 \mu \mathrm{m}$ in diameter to minutely bordered, mainly in tangential walls (fiber tracheids to libriform fibers); fibers approximately the same length as the vessel elements. Axial parenchyma absent or rare. Rays uniseriate (Fig. 11G) with occasional short biseriate portions, composed of elongate procumbent cells (Fig. 11E) with thick cell walls, often somewhat enlarged and with intercellular spaces, perforations in tangential and radial walls (Fig, 11F) of ray cells; ray height (1-)2-16 cells high, $137 \pm 55 \mu \mathrm{m}$, frequency $\sim 8$ per mm. Dark globules and spheroidal silica bodies (Fig. $11 \mathrm{I})$, generally one per cell, in ray cells.

Sample: S14 (12 cm in diameter). Other material: S142 $(30 \mathrm{~cm}), \mathrm{S} 145(20 \mathrm{~cm})$.

Affinity. The combination of solitary vessels, ray-vessel pits similar to intervessel pits, non-septate fibers, rays exclusively uniseriate with all procumbent cells and silica bodies (IAWA characters 9, 30, 66, 96, 104, 159, 160) occurs in the InsideWood database only in Dipterocarpaceae (Monotoideae) and Sarcolaenaceae. The most similar to the fossils are woods in Monotoideae (Marquesia, Monotes, Pseudomonotes). Axial parenchyma scanty paratracheal (a character not consistently coded for but apparently

Figure 11. Dipterocarpaceae cf. Pseudomonotes. - A: Diffuse porous wood, TS. - B: Growth ring marked by radially flattened fibers and sparse vessels, TS. - C: Thick- to very thick-walled fibers, TS. - D: Vessel-fiber pits uncrowded, TLS. - E: Rays of procumbent cells and with silica bodies, RLS. - F: Rays with perforations (arrows), RLS. - G: Uniseriate rays, vessel element with long tail (arrow), TLS. - H: Vessel element tail with crowded pits, TLS. - I: Vesselray pits bordered, silica bodies in ray (arrow), RLS. - Scale bars $=200 \mu \mathrm{m}$ in A; $50 \mu \mathrm{m}$ in G: $40 \mu \mathrm{m}$ in $\mathrm{B}, \mathrm{E} ; 20 \mu \mathrm{m}$ in $\mathrm{C}, \mathrm{D}, \mathrm{H}, \mathrm{I} ; 10 \mu \mathrm{m}$ in $\mathrm{F}$. 


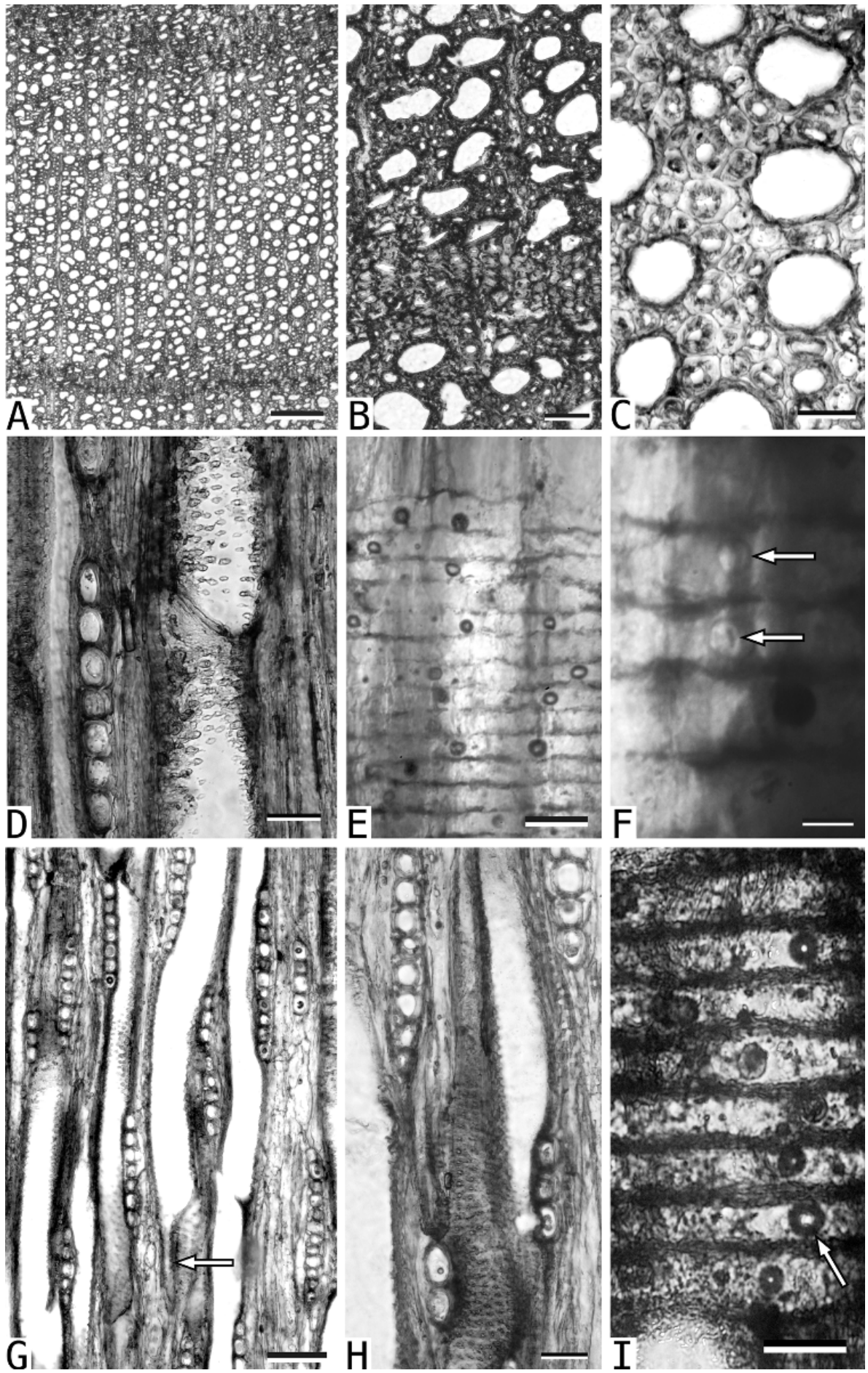


uniformly present based on review of the literature and available databases), vessels predominantly solitary, and very thick-walled fibers are all typical of Dipterocarpaceae. Rays with short biseriate portions, fiber-tracheids, small intervessel pits, and homocellular rays and absence of canals (found in most Dipterocarpoideae) characterizes Monotoideae (Morton 1995; InsideWood 2004-onwards). The highly diverse Dipterocarpoideae are the dominant trees of Southeast Asian wet tropical forest, whereas Monotoideae and Pakaraimoideae, considered basal groups within the family (Dayanandan et al. 1999), occur in Madagascar and Africa, and also in South America, where they are represented by the monotypic genus Pseudomonotes. Monotoideae include taxa with vessel diameter $<50 \mu \mathrm{m}$ (Marquesia excelsa Fr., an African rainforest tree) and fiber bands similar to those seen in the fossil material (Monotes engleri Gilg) but not with sparse/absent axial parenchyma. New World Pseudomonotes tropenbosii A.C.Londoño, E. Alvarez \& Forero from the Colombian Amazon differs from the fossils in having wider vessels, heterocellular rays, and aliform paratracheal parenchyma (Morton 1995) but also shares many characters (rays with globular deposits and silica bodies and with thick walls, vessel elements with long tails, pits crowded in vessel tails, and presence of both fiber tracheids and libriform fibers) suggesting close affinity. Vascular tracheids are present in Marquesia and Monotes but absent in Pseudomonotes. Sarcolaenaceae, closely allied with Dipterocarpaceae, also show some similarities. This family has uniseriate rays with biseriate portions and fiber tracheids and libriform fibers as in the fossil material but has diffuse-in-aggregates parenchyma and generally lacks silica bodies (Den Outer \& Schütz 1981).

The many fossil woods referred to Dipterocarpaceae in the InsideWood database, mainly from the Tertiary of Asia, differ from the fossil specimens by some combination of wide/very wide vessels, multiseriate rays, and resin canals (InsideWood 2004onwards; Gregory et al. 2009).

The fossil shares distinctive features with Monotoideae - Pseudomonotes but also exhibits some differences from $P$. tropenbosii, the only New World representative of the family, and is therefore referred to the genus.

\section{Euphorbiaceae}

\section{HURA L.}

Hura chancayensis Woodcock, Meyer et Prado, sp. nov. (Fig. 12)

Diagnosis: Wood lacking growth rings, diffuse porous. Vessels solitary and in radial multiples of 2 to 9 , including dumbbell-shaped groups, mean tangential diameter $\sim 100$ $\mu \mathrm{m}$, perforations simple, intervessel pits crowded alternate, ray-vessel pits bordered to enlarged with reduced borders. Fibers non-septate. Axial parenchyma scanty paratracheal and diffuse to diffuse-in-aggregates. Rays uniseriate but occasionally with short biseriate portions, generally of exclusively procumbent cells. Crystals in axial parenchyma.

Etymology: Named after the Chancay River Valley, which lies below Sexi and the fossil site. 
Holotype: S178 (estimated diameter $15 \mathrm{~cm}$ ). Other material: S150 (estimated diameter $12 \mathrm{~cm}$ ).

Type locality: Piedra Chamana Fossil Forest main site, Sexi, Peru, associated with the lahar deposits.
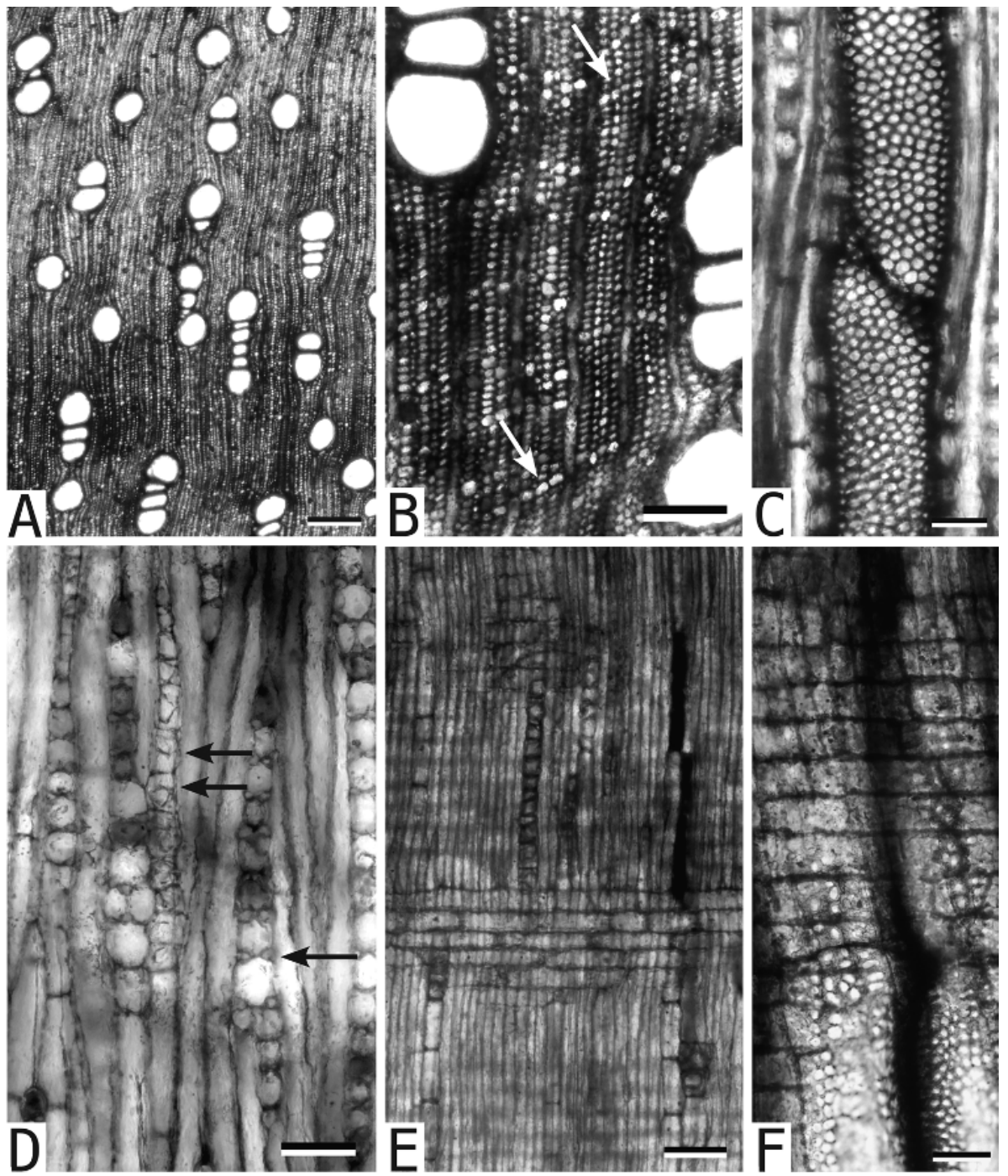

Figure 12. Hura chancayensis Woodcock, Meyer et Prado, sp.nov. - A: Vessels solitary and in radial multiples, dumbbell-shaped groupings, TS. - B: Axial parenchyma diffuse to diffuse-inaggregates (arrows), TS . - C: Intervessel pits crowded, polygonal, TLS. - D: Rays uniseri-ate with biseriate portions and intercellular spaces (arrow), crystals in chambered axial parenchyma (double arrow), TLS. - E: Rays of procumbent cells, crystals in axial parenchyma, RLS. - F: Vessel-ray parenchyma similar to intervessel pits to enlarged and with reduced borders, RLS. - Scale bars $=200 \mu \mathrm{m}$ in A; $100 \mu \mathrm{m}$ in B; $75 \mu \mathrm{m}$ in E; $50 \mu \mathrm{m}$ in D; $40 \mu \mathrm{m}$ in C, F. 
Description: Growth rings absent. Wood diffuse porous (Fig. 12A). Vessels solitary and in radial multiples of 2 to 9, occasionally longer, and including dumbbell-shaped vessel groups (Fig. 12A); tangential diameter $103 \pm 21 \mu \mathrm{m}, \sim 11$ per $\mathrm{mm}^{2}$; solitary vessels round in outline, perforations simple; intervessel pits crowded, alternate, polygonal, 8-10 um (Fig. 12C); vessel-ray and vessel-axial parenchyma pits similar to intervessel pits and enlarged with reduced borders, circular to elongate (Fig, 12F); vessel element length $359 \pm 91 \mu \mathrm{m}$. Fibers non-septate, very thin- to medium thick-walled, pitting not observed, length $685 \pm 204 \mu \mathrm{m}$. Axial parenchyma scanty paratracheal and diffuse to diffuse-in-aggregates (Fig. 12B), strands narrowly tapering at ends and intergrading morphologically with fibers; strand length $4-8$ cells. Rays almost exclusively uniseriate, (1-) 2 to 20 cells high, occasionally with very short biseriate portions (Fig. 12D), composed of procumbent cells (Fig. 12E), rarely with squarish cells at the margins, often with intercellular spaces (Fig. 12D); height $278 \pm 102 \mu \mathrm{m}, \sim 11$ per mm. Dark contents in axial parenchyma and rays. Crystals in chambered axial parenchyma, one per chamber, in chains of 3-5 (to 14), sometimes extending to the narrowly tapering ends of the strands (Fig. 12D, E).

Affinity. The combination of diffuse porous wood, simple perforation plates, fibers non-septate and very thin-walled, diffuse-in-aggregates parenchyma, and rays that are exclusively uniseriate, composed of exclusively procumbent cells, and 4-12 per $\mathrm{mm}^{2}$ (IAWA characters 2, 13, 66, 68, 77, 96, 104, 115) occurs in InsideWood in two genera of Euphorbiaceae - Euphorbioideae (Excoecaria agallocha L. and Hura crepitans L.) and in Lepidobotrys (Lepidobotryaceae). Vessels solitary and in radial multiples with dumbbell-shaped clusters, non-septate fibers, and rays with short biseriate portions and intercellular spaces are typical of Euphorbioideae (Mennega 2005). Hura shares most features with the fossil, including crystals in chambered axial parenchyma and low $(<500 \mu \mathrm{m})$ rays composed entirely of procumbent cells that distinguish the genus within the subfamily (Mennega 2005). Vessel-ray pits in Hura are described either as bordered and similar to intervessel pits or enlarged with reduced borders and parenchyma strands as 2-4 and 3-9 cells long. However, Hura generally has tyloses and larger intervessel pits (Richter \& Dalwitz 2000-onwards; Mennega 2005; León \& Chavarri 2006). The genus, with two species, occurs widely in the New World tropics, especially in riparian and swampy forests. Excoecaria agallocha (also Euphorbiaceae) differs from the fossil in lacking vessels in long radial multiples and having rays higher and less distinctly homocellular and crystals in rays rather than in axial parenchyma. Lepidobotrys staudtii Engl. (Lepidobotryaceae) also shares a large number of characters with the fossil but has minute intervessel pits and lacks other distinctive features of the fossil (dumbbellshaped vessel groupings, intercellular spaces in rays).

We have found no record of fossil wood referred to Hura. Euphorbioxylon Felix (1887) encompasses woods of generally euphorbiaceous affinity (Crawley 2001). Most of these fossils, which are mainly from the Old World (Gregory et al. 2009), differ from the fossil by some combination of multiseriate, heterocellular rays and septate fibers. One included species, Euphorbioxylon bridelioides Salard 1961 (1962) was described from a specimen collected near Sexi and possibly belongs to the same assemblage. This specimen is quite different from our fossil and has shorter vessel multiples, rays of two 
sizes (uniseriate and $>4-10+$ ? cells wide), and radial canals and appears unusual for Euphorbiaceae in having wide rays and vestured pits.

The fossil is most similar to Hura and is assigned to a newly erected fossil species within this genus.

\section{Fabaceae}

DALBERGIA L.f.

Dalbergia santa-rosa Woodcock, Meyer et Prado, sp. nov. (Fig. 13)

Diagnosis: Wood with distinct growth rings, semi-ring porous. Vessels solitary, in radial multiples of 2-3 in earlywood and 2-5 in latewood, tangential diameter 75-200 $\mu \mathrm{m}$, peforations simple; intervessel pits alternate, with vestured apertures; vessel-ray pits similar to intervessel pits but more crowded. Fibers non-septate. Axial parenchyma paratracheal scanty to aliform, diffuse, and in narrow marginal bands. Rays storied to irregularly storied, uniseriate and composed of all procumbent cells. Crystals in axial parenchyma.

Etymology: Named for Saint Rose, the patron saint of Sexi.

Holotype: S143 (9 cm in diameter). Other material: S60 (15 cm).

Type locality: Piedra Chamana Fossil Forest main site, Sexi, Peru, associated with the lahar deposits.

Description: Growth rings distinct, marked by changes in vessel diameter and density and marginal parenchyma (Fig. 13A,B). Wood semi-ring porous (to nearly ring porous) (Fig. 13A). Vessels solitary and in radial multiples of 2-3 in earlywood, 2-5 in latewood (Fig. 13A); earlywood vessels sometimes appearing diagonally arranged; mean tangential diameter $113 \mu \mathrm{m}$ (mode 75-100 $\mu \mathrm{m}$ with an outlier of 175-200 $\mu \mathrm{m}$ diameter vessels); vessels round to oval in outline, perforations simple, end walls horizontal; intervessel pits alternate, oval to circular, with oval to slit-like, sometimes coalescent apertures and vestures, 7-10 $\mu \mathrm{m}$ (Fig. 13E); ray-vessel pits bordered, similar to intervessel pits in size and shape but more crowded (Fig, 13F); vessel element length $277 \pm 71 \mu \mathrm{m}$. Fibers non-septate, medium- to very thick-walled, with minutely bordered pits in radial and tangential walls. Axial parenchyma sparsely scanty paratracheal and irregularly asymmetrically aliform (Fig. 13C), also diffuse (diffuse-in-aggregates) (Fig. 13D) and in narrow marginal bands 2 to 3 cells wide (Fig. 13B); in strands of (?2 to) 4 cells or of enlarged cells and then in strands of 4-8. Rays uniseriate (Fig. 13G), composed exclusively of procumbent cells (Fig. 13H); height $176 \pm 27 \mu \mathrm{m}, \sim 10$ per mm. Rays storied to irregularly storied (Fig. 13G). Dark contents in vessels. Crystals in chains of 4-8 in axial parenchyma, one per cell (Fig. 13 I,J).

Affinity. Wood semi-ring porous, rays exclusively uniseriate and storied, and crystals (IAWA characters 4, 96, 118, 136) occurs in Dalbergia and Pterocarpus (Fabaceae Papilionoideae - Dalbergieae) and in Faidherbia albida (Delile) A.Chev. (Fabaceae Mimosoideae) in the InsideWood database. Although usually not reliably determinable in fossil material, vestured pits, characteristic of Papilionoideae and Mimosoideae, are evident in the fossil. Dalbergia appears most similar to the fossil. Ring porous to semi-ring porous wood, marginal parenchyma, and crystals in chains of 11 or fewer distinguish or are typical of Papilionoideae within the legumes (Wheeler \& Baas 1992); 


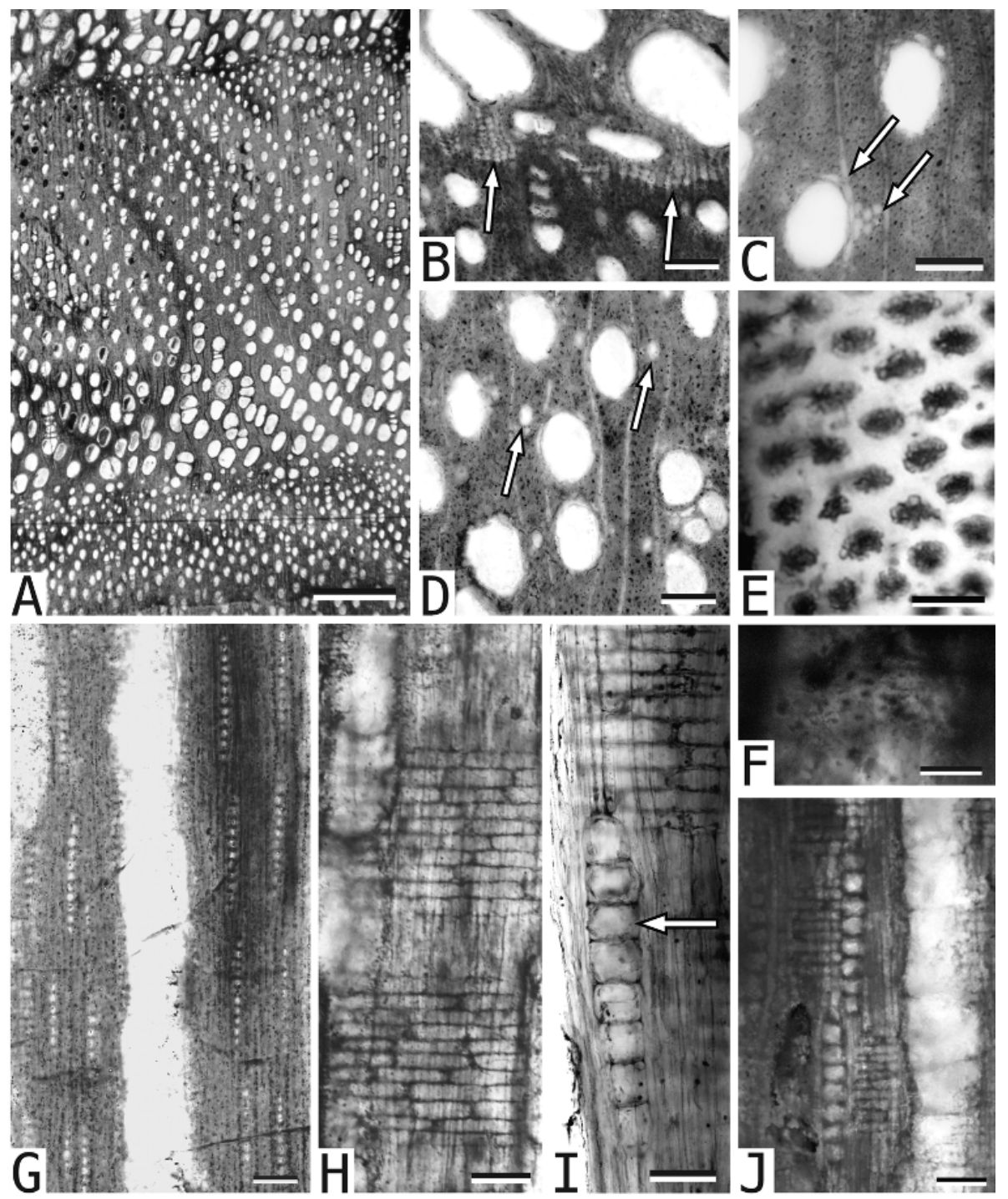

Figure 13. Dalbergia santa-rosa Woodcock, Meyer et Prado, sp. nov. - A: Wood semi-ring porous, TS. - B: Marginal parenchyma (arrows), TS. - C: Parenchyma scanty paratracheal and asymmetrically aliform (arrows), TS. - D: Diffuse parenchyma in latewood (arrows), TS. E: Oval to round intervessel pits with vestures, TLS. - F: Ray-vessel pits similar to intervessel pits, RLS. - G: Rays uniseriate, storied, TLS. - H: Rays composed of procumbent cells, RLS. - I: Enlarged axial parenchyma strand with crystals (arrow), TLS. - J: Crystals in chains of 8, RLS. - Scale bars $=1 \mathrm{~mm}$ in A; $100 \mu \mathrm{m}$ in B, C, D, H; $75 \mu \mathrm{m}$ in G; $50 \mu \mathrm{m}$ in $\mathrm{I}, \mathrm{J} ; 25 \mu \mathrm{m}$ in $\mathrm{F} ; 10 \mu \mathrm{m}$ in $\mathrm{E}$. 
asymmetrically aliform parenchyma has also been noted in the genus (Espinoza de Pernía \& León 2002). Dalbergia is a large ( 250 species) pantropical genus that is variable with respect to porosity and ray width. Parenchyma ranges from scanty paratracheal to aliform, aliform-confluent, and variably banded; most taxa have diffuse to diffuse-in-aggregates parenchyma, which is unusual in the subfamily (Espinoza de Pernía \& León 2002; Gasson et al. 2010). New World taxa comprise 40 species of shrubs, trees, and lianas. The fossil shows greatest similarity to taxa in New World Clade V-a of Dalbergia (Vatanparast et al. 2013), which appears, based on available descriptions (Richter et al. 1996; InsideWood 2004-onwards; Gasson et al. 2010), to be distinguished within the genus by the tendency toward semi-ring porosity and lack of abundant paratracheal or apotracheal parenchyma; D. decipularis Rizzini \& A. Mattos, occurring in Northeast Brazil dry forest, has a particularly similar vessel distribution pattern, differing from the fossil mainly in having 2-3-seriate rays. Pterocarpus, which is also similar, is likewise variably semi-ring porous and includes taxa with exclusively uniseriate rays and diffuse to diffuse-in-aggregates parenchyma, but most taxa have better-developed banding than the fossil and lack very thick-walled fibers.

Of described fossil woods, Dalbergioxylon Ramanujam (1960) differs from the fossil in being diffuse porous and having aliform-confluent parenchyma and 1-4-seriate rays. Fossil material referred to this genus is from the Paleogene and Neogene of Europe, Asia, and Africa (Gregory et al. 2009). We did not find records from the New World.

The fossil is most similar to Dalbergia, in particular New World clade V-a, and is assigned to a newly erected fossil species within this genus.

\section{CYNOMETRA L.}

\section{Cynometra grandis Woodcock, Meyer et Prado, sp. nov. (Fig. 14)}

Diagnosis: Wood with growth rings marked by marginal parenchyma and changes in vessel diameter, diffuse porous. Vessels solitary and in radial multiples, mostly of 2-3, mean tangential diameter 50-100 $\mu \mathrm{m}$, perforations simple; intervessel pits alternate; vessel-ray pits bordered, similar to intervessel pits. Fibers mainly non-septate. Parenchyma scanty paratracheal to vasicentric and unilaterally winged-aliform, also in short apotracheal bands. Rays storied, 1-2-seriate but predominantly biseriate, composed of all procumbent cells or with one to few marginal rows of (square to) upright and high procumbent cells. Prismatic crystals in axial parenchyma and fibers.

Etymology: The specific epithet refers to a specimen of this wood type, which is the largest fossil tree at the site.

Holotype: S152 $(25 \mathrm{~cm})$. Other material: S38 $(75 \mathrm{~cm}), \mathrm{S} 146(30 \mathrm{~cm})$.

Type locality: Fossil Forest Piedra Chamana main site, Sexi, Peru, associated with the lahar deposits.

Description: Growth rings marked by marginal parenchyma and occasional narrow vessels along the boundary (Fig. 14A,B). Wood diffuse porous (Fig. 14A). Vessels solitary and in radial multiples of 2-3 (4-6) (Fig. 14A); tangential diameter $178 \pm 31 \mu \mathrm{m}$, density $20 \pm 5$ per $\mathrm{mm}^{2}$; vessels round to oval in outline, perforations simple; intervessel pits crowded, alternate, polygonal, $\sim 5 \mathrm{~m}$ (Fig. 14C); vessel-ray and vessel-axial 
parenchyma pits bordered, similar to intervessel pits (Fig. 14D); vessel element length $305 \pm 41 \mu \mathrm{m}$. Fibers generally non-septate, but occasionally with thin septae, thin- to thick-walled, $400 \mu \mathrm{m}$ long, pitting not observed. Parenchyma scanty paratracheal to vasicentric, unilaterally and often asymmetrically aliform with long wings, and confluent; also in short apotracheal bands (Fig. 14A,B); wings and apotracheal bands wavy, 3-4 cells wide; also marginal in incomplete bands 1-3 cells wide (Fig. 14B);

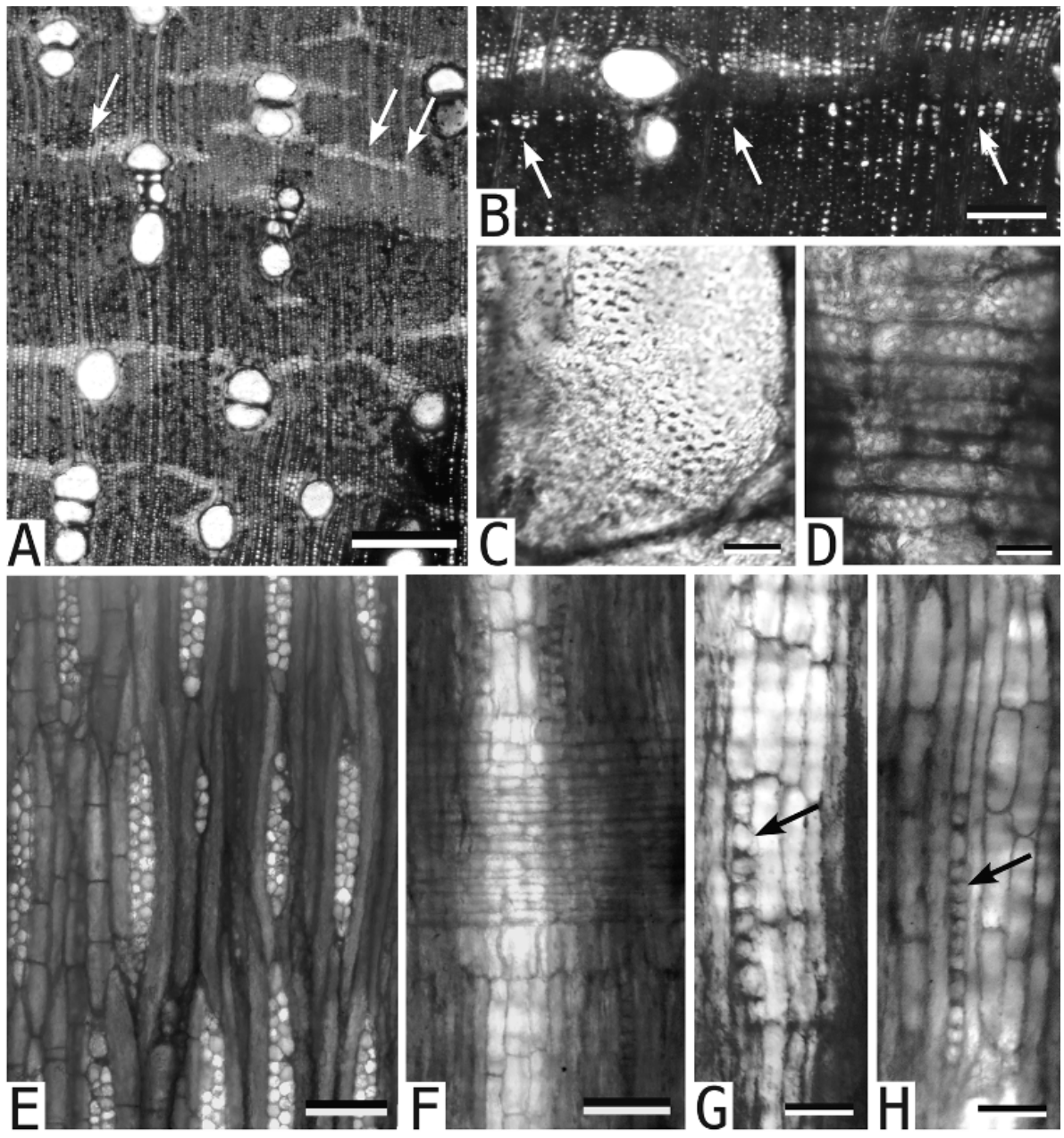

Figure 14. Cynometra grandis Woodcock, Meyer et Prado, sp.nov. - A: Wood diffuse porous, vessels solitary and in short radial multiples, parenchyma paratracheal-aliform (arrow) and in apotracheal bands (double arrow), TS. - B: Marginal parenchyma, TS. - C: Small intervessel pits, TLS. - D: Vessel-ray pits similar to intervessel pits, RLS. - E: Rays 1-2(-3)-seriate and storied, fibers and axial parenchyma irregularly storied, axial parenchyma in strands of 4,TLS. - F: Ray with one row of upright marginal cells, RLS. - G: Crystals in chambered axial parenchyma, RLS. - H: Crystals in chambered fiber, RLS. - Scale bars $=500 \mu \mathrm{m}$ in A; $200 \mu \mathrm{m}$ in B; 100 $\mu \mathrm{m}$ in $\mathrm{E}, \mathrm{F} ; 50 \mu \mathrm{m}$ in $\mathrm{G}, \mathrm{H} ; 25 \mu \mathrm{m}$ in $\mathrm{C}, \mathrm{D}$. 
in strands of 4-8 cells (Fig. 14E). Rays 1-2(-3)-seriate but predominantly biseriate (Fig. 14E); composed of all procumbent cells or, more commonly, with procumbent body ray cells and one to few marginal rows of (square to) upright and high procumbent cells (Fig. 14F), height $263 \pm 49 \mu \mathrm{m}, \sim 9$ per mm. Rays storied; axial parenchyma and fibers irregularly storied (Fig. 14E). Dark contents in vessels. Prismatic crystals in chambered axial parenchyma strands and fibers (Fig. 14G,H), often at the periphery of the vasicentric sheath; 4-5 to 19 crystals per strand.

Affinity. In the InsideWood database the combination of axial parenchyma wingedaliform and in strands of 4-8 and rays both of all procumbent cells and with one row of square to upright marginal cells and storied (IAWA characters 80, 82, 92, 93, 104, 106, 118 with 90,91 absent) occurs in Cynometra (Fabaceae - Detarieae) and Entandrophragma (Meliaceae). The closest match appears to be Cynometra. Simple perforation plates, vessel-ray pits similar to intervessel pits, and axial parenchyma aliform, banded / confluent, and/or marginal are consistent with placement in Fabaceae. Although high diversity and recent taxonomic changes make it difficult to reference specific characteristics of Detarieae, New World (Venezuelan) taxa generally have non-septate fibers and heterocellular, 2-3-seriate rays (Melandri \& Espinoza de Pernía 2009) as seen in the fossil. Small to very small intervessel pits (considered distinctive for Cynometra and allied genera), apotracheal parenchyma generally in wavy bands, and crystals in rays and/or axial parenchyma are noted for the Cynometra group within the subtribe (Gasson et al.2003). Cynometra is a large, pantropical genus ( 70 species, $\sim 25$ in the New World) of shrubs and trees occurring most frequently in riparian or seasonally flooded forest but also in dry forest (Lewis et al. 2005). The genus is variable in ray composition (1- to 4-10-seriate, homocellular to heterocellular), presence of storied structure, and axial parenchyma strand length (to 8 cells). Parenchyma bands narrow (1-4 cells wide), wavy, and unilateral paratracheal, together with marginal parenchyma, appear to be consistent features of the genus. Taxa included in the genus have axial parenchyma patterns in many cases nearly identical to the fossil (C. ananta Hutch. \& Dalziel) and crystals in both axial parenchyma and fibers (C. alexandri C.H.Wright). Among other legumes, Caesalpinia includes species (e.g., C. coriaria (Jacq.) Willd.) that are similar to the fossil, but this genus generally has larger intervessel pits and shorter parenchyma strands. Some Meliaceae (Entandrophragma species) are also similar, but this family generally has minute intervessel pits and longer vessel elements and fibers (Klaassen 1999).

A considerable amount of fossil material from Asia and Africa has been referred to Cynometra or Cynometroxylon (Gregory et al. 2009; Mehrotra et al. 2011). Of the nine taxa of Cynometroxylon included in the InsideWood (2004-onwards) database, as well as Cynometroxylon holdenii (Gupta) Prakash \& Bande (Mehrotra et al. 2011), none has the pattern of aliform and banded parenchyma and rays 1-3-seriate and storied as seen in our fossil. Cynometroxylon dakshinese Navale, from the Tertiary of Burma, has banding and ray structure similar to the fossil and is described as having storied rays (Prakash \& Bande 1977 (1980)).

The fossil shows greatest similarity to extant Cynometra and is assigned to a newly erected fossil species within this genus. 


\section{PRIORIA Griseb.}

Prioria elbaiae Woodcock, Meyer et Prado, sp. nov. (Fig. 15)

Diagnosis: Wood with distinct growth rings marked by marginal parenchyma, diffuse porous. Vessels solitary and in radial multiples of 2-3, mean tangential diameter $100-200 \mu \mathrm{m}$, vessel density $\leq 5$ per $\mathrm{mm}^{2}$, perforations simple; intervessel pits alternate; vessel-ray pits similar to intervessel pits. Fibers septate and non-septate, wide fibers associated with axial parenchyma in an irregular lozenge-aliform to confluent pattern. Axial parenchyma scanty paratracheal to vasicentric and marginal. Rays nonstoried, 1-3-seriate, low uniseriate rays of all upright cells, heterocellular rays with procumbent body cells and 1(-3-4) rows of upright to square marginal cells. Axial canals dispersed and often paired tangentially. Prismatic crystals in chambered fibers and axial parenchyma.

Etymology: Named after Elba Davila, long-time friend of the scientific project in Sexi.

Holotype: S54C (16 cm in diameter).

Type locality: Piedra Chamana Fossil Forest main site, Sexi, Peru, associated with the lahar deposits.

Description: Growth rings marked by marginal parenchyma (Fig. 15A). Wood diffuse porous (Fig. 15A). Vessels solitary and in radial multiples of 2-3 (Fig. 15A,B); tangential diameter $151 \pm 24 \mu \mathrm{m}$, density $\sim 3$ per $\mathrm{mm}^{2}$; vessels round in outline, perforations simple, end walls oblique; intervessel pits alternate, oval with oval and often coalescent apertures, $\sim 5-8 \mu \mathrm{m}$ (Fig. 15D); vessel-ray and vessel-axial parenchyma pits similar in size and shape to intervessel pits; vessel element length $405 \pm 59 \mu \mathrm{m}$. Fibers non-septate and also with thin, often closely spaced septae (Fig. 15 I); dimorphic, including long narrow fibers and shorter, wider (parenchyma-like) fibers associated with paratracheal parenchyma in an irregularly lozenge-aliform or confluent pattern; thin- to thick-walled (Fig. 15C); minutely pitted in radial walls. Axial parenchyma scanty paratracheal (Fig. 15C) to vasicentric, also marginal in narrow bands (Fig. 15A); in strands of 2-4 (possibly more) cells. Rays non-storied, (1-)2-3-seriate (Fig. 15H); low uniseriate rays of mainly upright cells; the majority of rays with procumbent body cells and 1 or, less commonly, 2 to 4 rows of square to upright marginal cells (Fig. 15 J); ray height $646 \pm$ $234 \mu \mathrm{m}$ (to 40-50 cells high), density $\sim 5$ per mm. Rays occasionally fused vertically by means of short uniseriate extensions. Axial intercellular canals dispersed through the wood and often paired tangentially, 60-130 $\mu \mathrm{m}$ in diameter (Fig. 15B,E,F). Prismatic

Figure 15. Prioria elbaiae Woodcock, Meyer et Prado, sp.nov. - A: Vessels solitary and in radial pairs, growth boundary with marginal parenchyma and partly collapsed axial canals (arrows), TS. - B: Axial canals (arrows), TS. - C: Scanty paratracheal parenchyma, thin-walled fibers, TS. - D: Intervessel pits oval with coalscent apertures, TLS. - E: Paired axial canals, narrow fibers (arrow), TS. - F: Axial canal (arrow), TLS. - G: Chambered crystalliferous fibers, RLS.H: Rays 1-3-seriate, TLS. - I: Septate fibers (arrows), TLS. - J: Ray with one marginal row of square to upright cells, RLS. - Scale bars $=250 \mu \mathrm{m}$ in A; $200 \mu \mathrm{m}$ in B, F; $100 \mu \mathrm{m}$ in C, E, H, J; $50 \mu \mathrm{m}$ in $\mathrm{G}, \mathrm{I} ; 25 \mu \mathrm{m}$ in $\mathrm{D}$. 


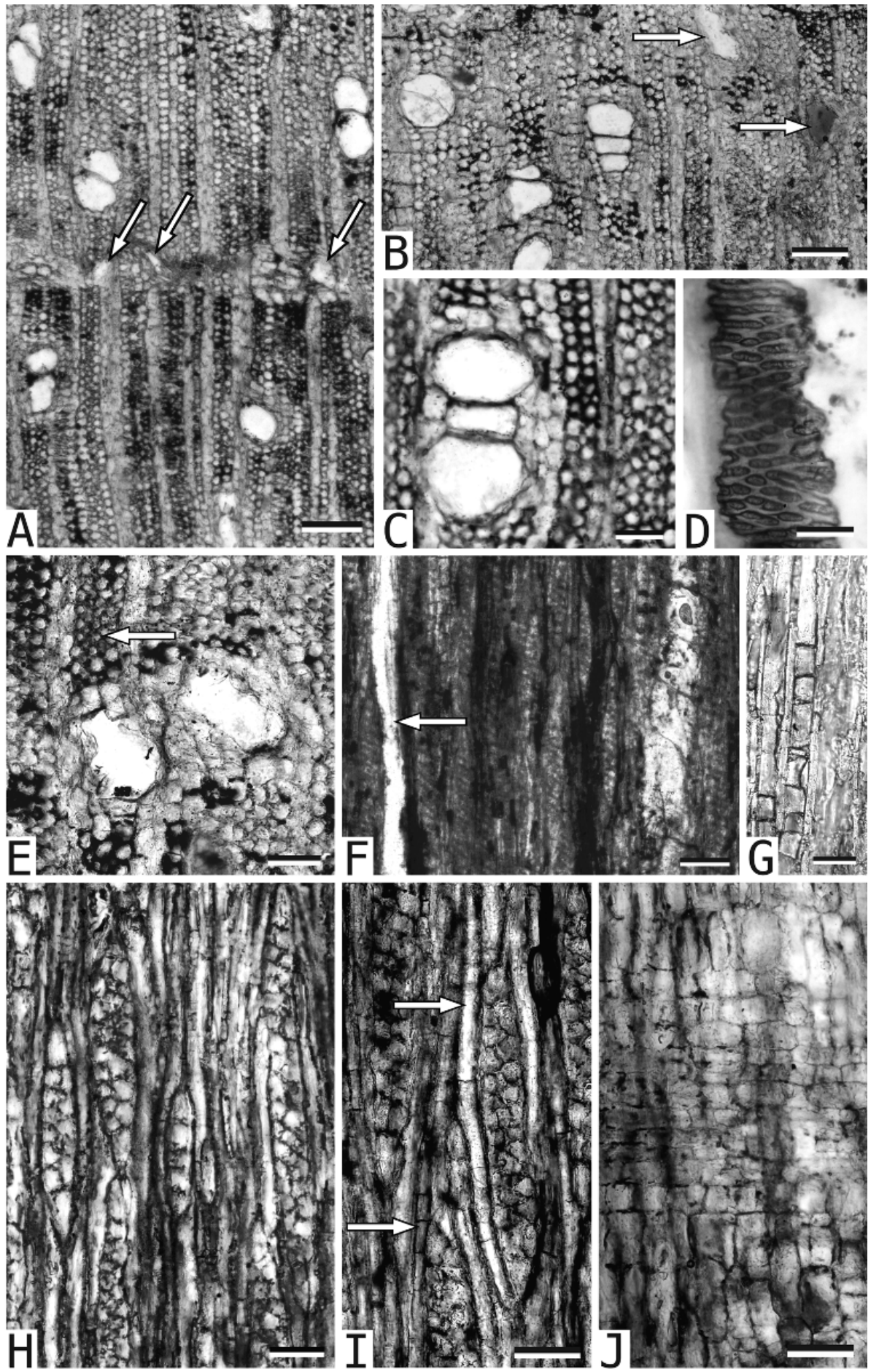




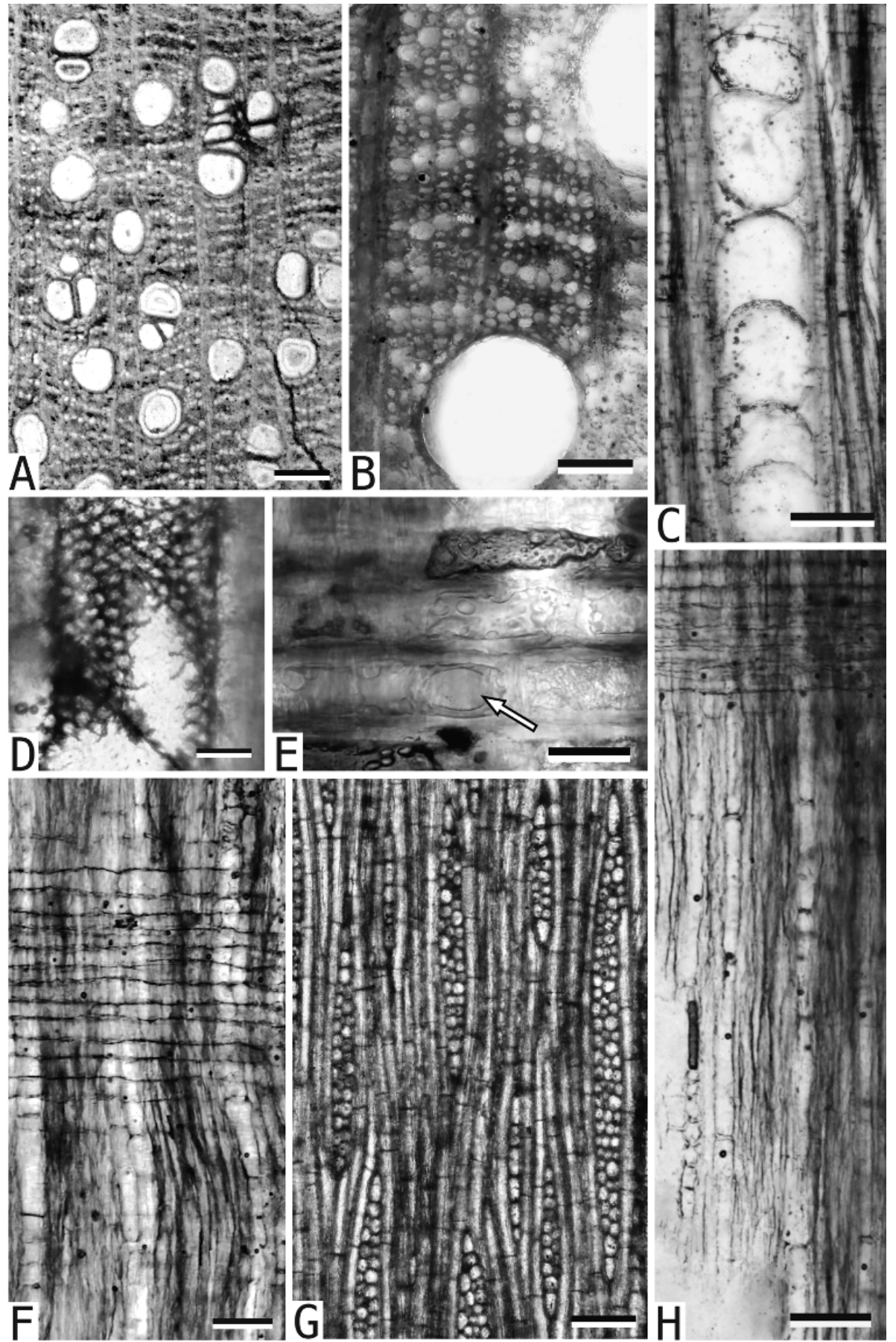


crystals in chambered fibers (Fig. 15G), less commonly observed in axial parenchyma; chain length not determined.

Affinity. The combination of vessel density $\leq 5$ per $\mathrm{mm}^{2}$, rays of procumbent cells with one row of marginal/square cells and unstoried, axial canals diffuse and not in long tangential lines or of traumatic origin, and prismatic crystals (IAWA characters 46, 106, 129, and 136 with 118, 127, and 131 absent) occurs only in the Prioria s.s. clade (Fabaceae - Detarieae) in the InsideWood database. Taxa in this clade, including Oxystigma, Gossweilerodendron, and Kingiodendron (all now being reassigned to Prioria; Fougère-Danezan et al.2010), are distinguished within Fabaceae by dispersed axial canals (Banks \& Gasson 2000). The axial canals in this group are commonly paired tangentially (see photographs in Banks \& Gasson 2000). Prioria copaifera Griseb., occurring in back-mangal and seasonally flooded forests in Central America and Colombia, is the only New World taxon. Variable axial parenchyma pattern and intergrading fibers and axial parenchyma have been noted in Prioria and other taxa in the clade (Banks \& Gasson 2000). Although Prioria (P. copaifera) is described as having short fibers (Banks \& Gasson 2000), material in wood slides collections (Aw) has both long, narrow and short, wide fibers; other shared features observed in collections material are short fibers intergrading with axial parenchyma, fibers that are occasionally septate (particularly near axial parenchyma sheaths), and crystals in fibers and axial parenchyma.

Among fossil woods, Kingiodendron Awasthi \& Prakash (1986 (1987); Guleria et al . 2001), with similarity to the modern genus (now being subsumed in Prioria), has wider vessels and axial canals than the fossil and is not described as having dimorphic fibers (although having similar irregularly aliform to confluent paratracheal banding). Included species (Prakash 1986; Guleria et al. 2001) are from the Tertiary of northern India.

The fossil shows closest correspondence to New World Prioria and is assigned to a newly erected fossil species within this genus.

\section{Lecythidaceae}

\section{CARINIANa Casar.}

Cariniana valverdei Woodcock, Meyer et Prado, sp. nov. (Fig. 16)

Diagnosis: Wood with indistinct growth rings, diffuse porous. Vessels solitary, in short radial multiples, and irregularly grouped, mean tangential diameter 100-200 $\mu \mathrm{m}$, with tyloses; perforations simple; intervessel pits crowded alternate; ray-vessel pits both bordered and enlarged with reduced borders. Fibers non-septate. Parenchyma scanty paratracheal and in narrow apotracheal bands. Rays non-storied, 1-4-seriate,

Figure 16. Cariniana valverdei Woodcock, Meyer et Prado, sp. nov. - A: Vessels solitary and in irregular groups, banded parenchyma, TS. - B: 1(-2)-seriate parenchyma bands, TS. - C: Vessel with tyloses, RLS. - D: Alternate intervessel pits, TLS. - E: Ray-vessel pits small and bordered and also enlarged (arrow), RLS. - F: Rays of procumbent cells, RLS. - G: 1-3-seriate rays, TLS. - H: Silica bodies in rays and axial parenchyma, crystals in chambered axial parenchyma, RLS. - Scale bars $=250 \mu \mathrm{m}$ in $\mathrm{A} ; 200 \mu \mathrm{m}$ in $\mathrm{C}, \mathrm{H} ; 100 \mu \mathrm{m}$ in $\mathrm{B}, \mathrm{F}, \mathrm{G} ; 75 \mu \mathrm{m}$ in $\mathrm{F} ; 25 \mu \mathrm{m}$ in D, E. 
composed of all procumbent cells or with squarish cells at the margins. Crystals in axial parenchyma; silica bodies in rays and axial parenchyma.

Etymology: Named after Luis Valverde, who was instrumental in bringing the fossils to the attention of science.

Holotype: S174 (22 cm in diameter). Other material: S140 $(22 \mathrm{~cm})$.

Type locality: Piedra Chamana Fossil Forest main site, Sexi, Peru, associated with the lahar deposits.

Description: Growth rings indistinct (Fig. 16A). Wood diffuse porous (Fig. 16A). Vessels solitary and in short radial multiples, including some irregular radial and tangential groupings (Fig. 16A); tangential diameter $153 \pm 34 \mu \mathrm{m}$, density $\sim 7$ per $\mathrm{mm}^{2}$; vessels round in outline, perforations simple, end walls oblique, with possible wall sculpturing; intervessel pits crowded, alternate, polygonal, 7-10 $\mu \mathrm{m}$, with small and oval to slit-like apertures (Fig. 16D); ray-vessel pits bordered and similar to intervessel pits but somewhat smaller $(\sim 5 \mu \mathrm{m})$ to enlarged with reduced borders $(8-30 \mu \mathrm{m}$ in diameter) (Fig. 16E); vessel element length $384 \pm 88 \mu \mathrm{m}$. Tyloses present (Fig. 16C). Fibers non-septate, thin- to thick-walled, minutely pitted in radial and tangential walls; tangential diameter 20-25 $\mu \mathrm{m}$. Axial parenchyma scanty paratracheal and in bands 1(-2-3) cell(s) wide alternating with 2- to 4-cell-wide fiber bands (Fig. 16B); cells wider than adjacent fibers; in strands of 4-8 cells. Rays 1-4-seriate (Fig. 16G), composed of procumbent cells (Fig. 16F) including very narrow cells, often with 1-3 rows of high procumbent to squarish cells at the margins, occasionally with square cells intermixed; height $370 \pm 169 \mu \mathrm{m}, \sim 5$ per mm. Rhomboidal crystals in chambered axial parenchyma cells (Fig. 16H), in chains of 4 to 10 or more. Small round silica bodies in rays and axial parenchyma (Fig. 16H).

Affinity. In the InsideWood database, the combination of medium intervessel pits, narrowly banded axial parenchyma, rays of exclusively procumbent cells, crystals in axial parenchyma, and silica bodies in rays (IAWA characters 26, 86, 104, 142, 160) is restricted to Lecythidaceae - Lecythidoideae (Allantoma, Cariniana, Couratari, Eshweilera, and Lecythis). Vessels solitary and in multiples with simple perforations, alternate intervessel pits, fibers with simple to minutely bordered pits, narrowly banded parenchyma, and prismatic crystals occur commonly in Lecythidaceae (Lens et al. 2007). Rays predominantly $2-4$-seriate, $<1 \mathrm{~mm}$ high, with silica bodies, and lacking crystals and occurrence of two types of vessel-ray pits generally distinguishes Lecythidoideae within the family (Lens et al. 2007). Lecythidoideae are tropical forest trees restricted to the New World that are dominants in Amazon forests and include many emergent tree species. Cariniana, Couratari, and Lecythis share most characters with the fossil. Cariniana and Couratari, which are very similar in anatomy (Bernal et al. 2011), generally have rays 1-2(-3)-seriate but include taxa (Cariniana estrellensis (Raddi) Kuntze, Couratari guianensis Aubl.) with wider rays (InsideWood 2004onwards). Of the two, only Cariniana has silica bodies in both ray and axial parenchyma, which is rare in Lecythidaceae (Lens et al. 2007). Cariniana (18 species) and Couratari (20 species) are genera of large emergent trees occurring mainly in South American lowland forest. Most species of Lecythis differ from the fossil in having thick- to very thick-walled fibers and wider parenchyma bands (Lens et al. 2007). 
Carinianoxylon (Selmeier 2003), from the Tertiary of Northeast Brasil, is very similar to the fossil but has rays 1-2-seriate; ray-vessel pitting and silica bodies are not described.

The fossil shows the greatest number of correspondences, including features considered diagnostic at the subfamily and genus level, with Cariniana and is assigned to a newly erected fossil species within this genus.

\section{Lythraceae}

\section{LAGERSTROEMIA L.}

The three wood types with apparent affinity to Lagerstroemia have the following characteristics: Vessels solitary and in radial multiples, solitary vessels often or mostly oval in outline, perforations simple; intervessel pits alternate, round or oval to polygonal, 5-10 $\mu \mathrm{m}$ in diameter; ray-vessel pits bordered, similar to intervessel pits (Fig. 17C,D, 18E,F, 19C,E); vessel element length 250-360 $\mu \mathrm{m}$. Fibers with fine septae at least in part (Fig. 17 I, 18 G, 19G); dimorphic, including narrow fibers and wider fibers associated with axial parenchyma in paratracheal groupings or bands. Rays exclusively or predominantly uniseriate and composed of procumbent cells, 5-7 per $\mathrm{mm}^{2}$. Crystals, when present, in chambered fibers.

The main differences among these wood types relate to presence/absence of growth rings, whether diffuse or semi-ring porous, occurrence of vessels at low density $(\leq 5$ per $\mathrm{mm}^{2}$ ), length of radial multiples, banding pattern, ray width, and occurrence of crystals. Wood type II also has a distinctive vessel diameter distribution and banding pattern. These differences are summarized in Table 2.

Lythraceae cf. Lagerstroemia I (Fig. 17)

Specimen: S10 (10 cm in diameter). Other material: S13 $(14 \mathrm{~cm}), \mathrm{S} 127(17 \times 29$ $\mathrm{cm}$ ). Specimen S127 was in situ in the ashfall deposit at location SX-06 (UTM 17M 71724 92783).

Additional description: Growth rings absent or indistinct (Fig. 17A). Wood diffuse porous (Fig. 17A). Vessel groupings consisting of radial multiples or irregular clusters of $2-4(-5)$, solitary vessels occasionally tangentially arranged or in tangential groups of

Table 2. Comparison of the Piedra Chamana Lagerstroemia wood types.

$\mathrm{GR}=$ growth rings, $\mathrm{DP}=$ diffuse porous, $\mathrm{VDen} \leq 5=$ vessel density $\leq 5$ per $\mathrm{mm}^{2}$, Rad $\mathrm{x}$ 's $=$ number of vessels per radial multiple, $\mathrm{RW}=$ ray width in cell numbers.

\begin{tabular}{lccccccc}
\hline & GR & DP & VDen $\leq 5$ & Rad x's & Banding & RW & Crystals \\
\hline Lagerstroemia I & - & + & + & $2-4$ & $\begin{array}{l}\text { wide para- } \\
\text { tracheal bands }\end{array}$ & $1-2$ & $\begin{array}{l}\text { crystals in fibers } \\
\text { and axial paren- } \\
\text { chyma }\end{array}$ \\
Lagerstroemia II & + & - & - & 2 & $\begin{array}{l}\text { narrow paratra- } \\
\text { cheal bands link- } \\
\text { ing solitary late- } \\
\text { wood vessels }\end{array}$ & 1 & crystals in fibers \\
Lagerstroemia III & + & - & - & $2-8$ & banding not clear & 1 & - \\
\hline
\end{tabular}




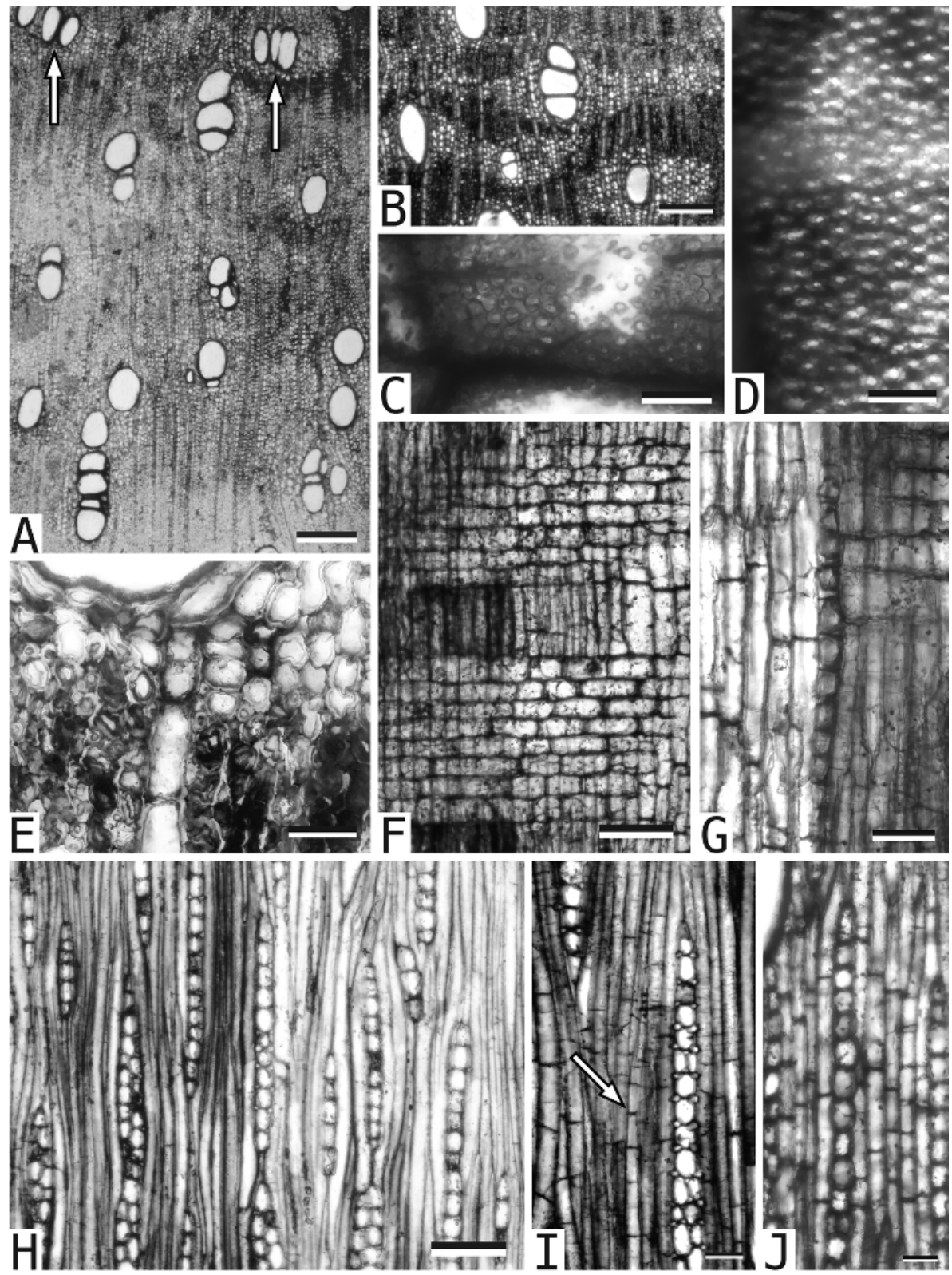

Figure 17. Lythraceae cf. Lagerstroemia I. - A: Vessels solitary, in radial multiples of 2-5, and tangentially arranged (arrows), TS. - B: Lozenge-aliform and confluent paratracheal banding, TS. - C: Bordered vessel-ray pits, RLS. - D: Alternate intervessel pits, TLS. - E: Gelatinous fibers, TS. - F: Rays of procumbent cells, RLS. - G: Chambered crystalliferous fiber, TLS. H: Rays 1-2-seriate, dimorphic fibers (narrow fibers left side of photo), TLS. - I: Septate fibers (arrow), ray with intercellular spaces, TLS . - J: Axial parenchyma in strands of 4, TLS. Scale bars $=250 \mu \mathrm{m}$ in $\mathrm{A} ; 200 \mu \mathrm{m}$ in $\mathrm{B} ; 100 \mu \mathrm{m}$ in $\mathrm{F}, \mathrm{H} ; 40 \mu \mathrm{m}$ in $\mathrm{E}, \mathrm{I} \mathrm{J} ; 25 \mu \mathrm{m}$ in C, D, G. 
2-3 (Fig. 17A); tangential diameter $156 \pm 42 \mu \mathrm{m}$, frequency $\sim 5$ per $\mathrm{mm}^{2}$; intervessel pits with round (to oval) apertures, 7-10 $\mu \mathrm{m}$ (Fig. 17D). Fibers thin- to thick-walled; parenchyma-like fibers intergrading with axial parenchyma in irregular, 8-10-cell wide paratracheal aliform sheaths or confluent bands (Fig. 17B,H), also in narrow (1 to 4 cells wide) apotracheal bands; fibers often gelatinous in appearance (Fig. 17E); pitting not observed; thick-walled fiber length $\sim 820 \mu \mathrm{m}$, parenchyma-like fiber length $\sim 490 \mu \mathrm{m}$. Axial parenchyma scanty paratracheal to vasicentric; in strands of 2 to 4 cells (Fig. 17J). Rays 1-2-seriate, but predominantly uniseriate (Fig. 17H); composed of exclusively procumbent cells (Fig. 17F), with intercellular spaces (Fig. 17 I); uniseriate rays frequently with short biseriate portions; ray height $2-38$ cells $(375 \pm 161 \mu \mathrm{m})$, frequency $\sim 7$ per mm. Dark contents in vessels. Prismatic crystals in chambered fibers (Fig. 17 I) and axial parenchyma, generally at the periphery of the vascular sheath; one crystal per chamber.

\section{Lythraceae cf. Lagerstroemia II (Fig. 18)}

Specimen: $\mathrm{S} 70$ (5+ $\mathrm{cm}$ in diameter).

Additional description: Growth rings distinct, marked by changes in vessel size and density (Fig. 18A,B). Wood semi-ring porous (Fig. 18A). Vessels including wide vessels in the early wood and narrow vessels distributed throughout the ring, with the widest vessels often not occurring at the growth ring boundary; wide vessels solitary and in radial pairs; narrow vessels solitary, in short radial multiples, and embedded in tangential bands of parenchyma-like fibers (Fig. 18A); vessel diameter distribution with a modal range of 50-75 $\mu \mathrm{m}$ and an outlier of wide, $\sim 150 \mu \mathrm{m}$ diameter vessels; intervessel pits (3-4) 5-6 $\mu \mathrm{m}$. Fibers medium- to very thick-walled; wider fibers, often with black contents and intercellular spaces (Fig.18D), forming narrow confluent bands linking the solitary latewood vessels (Fig. 18A,D); fiber length not determined. Axial parenchyma scanty paratracheal; strand length not determined. Rays uniseriate (Fig. 18 I), composed of exclusively procumbent cells (Fig. $18 \mathrm{~J}$ ); rays 4-18 cells high, $211 \pm 70 \mu \mathrm{m}$; frequency $\sim 7$ per mm. Parenchyma-like fibers often with black contents (Fig. 18A,D). Dark reddish-brown material in vessels. Crystals in chambered fibers (Fig. 18H).

\section{Lythraceae cf. Lagerstroemia III (Fig. 19)}

Specimens: S41 (3-3.5 cm in diameter). Other material: S167 $(2.5-3 \mathrm{~cm})$.

Additional description: Growth rings distinct, marked by changes in vessel diameter and density and marginal parenchyma-like fibers (Fig. 19A). Wood semi-ring porous (Fig. 19A). Vessel groupings consisting of radial multiples of 2 to 8+ (Fig. 19A); vessel diameter distribution with a modal value of 40-50 $\mu \mathrm{m}$ and an outlier of wider vessels 110-140 $\mu \mathrm{m}$; intervessel pits 5-8 $\mu \mathrm{m}$. Vascular tracheids associated with narrower vessels (Fig. 19 I). Fibers very thin- to very thick-walled; wider, parenchyma-like fibers in aliform to short-banded paratracheal sheaths (Fig. 19B) and also marginal, minutely pitted in radial walls; narrow fibers (Fig. 19G) $450 \mu \mathrm{m}$ long, parenchyma-like fibers (Fig. 19F,I) $205 \mu \mathrm{m}$ long. Axial parenchyma scarce or absent. Rays uniseriate (Fig. 19D), of weakly procumbent cells or occasionally with a row of squarish cells at the margins (Fig. 19F); height $2-12$ cells $(135 \pm 44 \mu \mathrm{m})$, frequency $\sim 5$ per mm. Dark contents in vessels. Crystals not observed. 


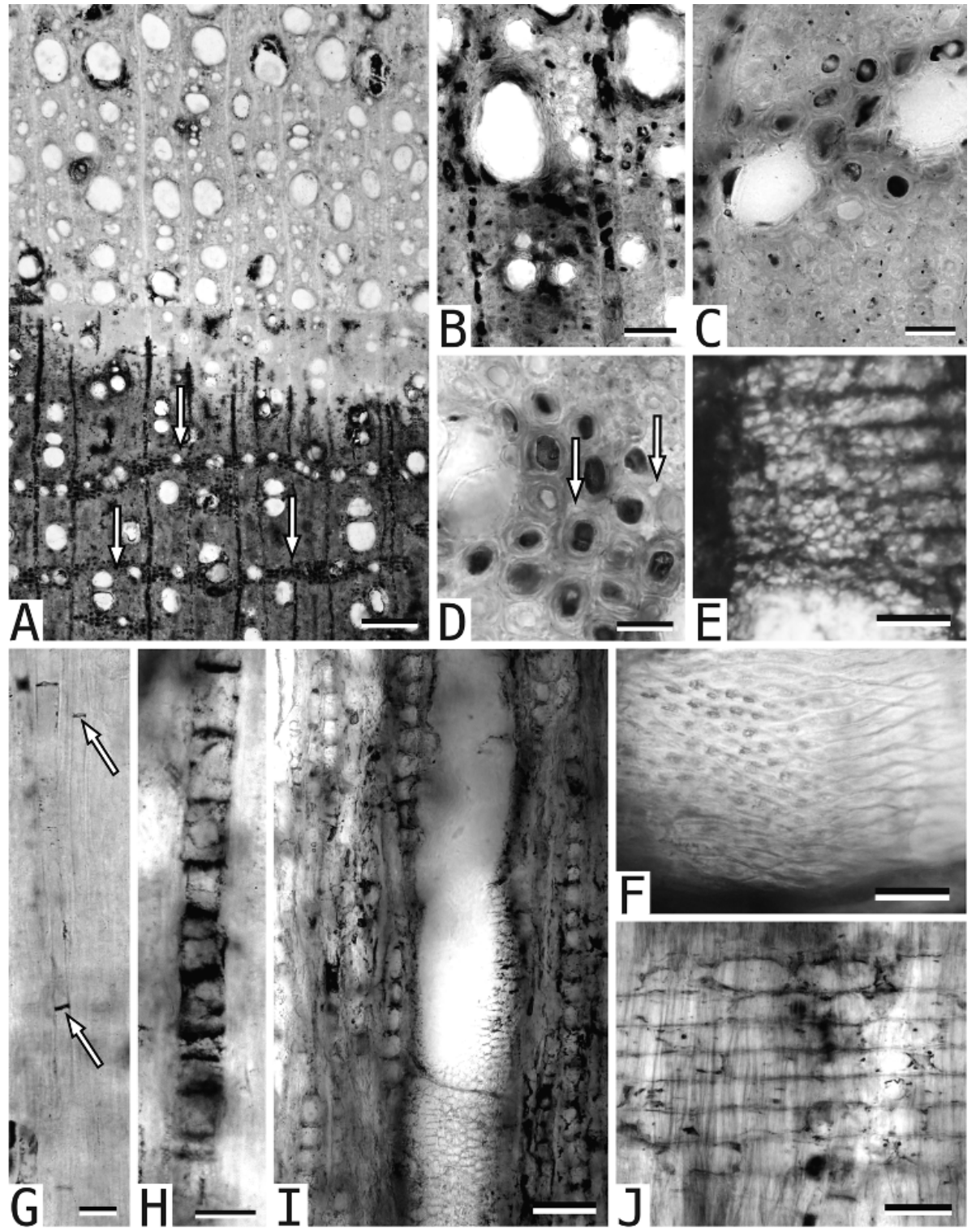

Figure 18. Lythraceae cf. Lagerstroemia II. - A: Semi-ring porous wood with vessels solitary and in radial pairs, parenchyma-like fiber bands (arrows), TS. - B: Growth ring marked by changes in vessel diameter and density, TS . - C: Parenchyma-like fibers associated with narrow vessels, thick-walled fibers (lower part of photo), TS. - D: Fibers with intercellular spaces (arrows), TS. - E: Ray-vessel pits similar to intervessel pits or with somewhat reduced borders, RLS. - F: Alternate intervessel pits, TLS. - G: Fibers with septae (arrows), RLS. - H: Crystals in chambered fiber, RLS. - I: Uniseriate rays, TLS. - J: Ray of procumbent cells, RLS. - Scale bars $=200 \mu \mathrm{m}$ in $\mathrm{A} ; 100 \mu \mathrm{m}$ in $\mathrm{I} ; 50 \mu \mathrm{m}$ in $\mathrm{B} ; 40 \mu \mathrm{m}$ in J; $25 \mu \mathrm{m}$ in C, D, E, F; $20 \mu \mathrm{m}$ in $\mathrm{G}, \mathrm{H}$. 

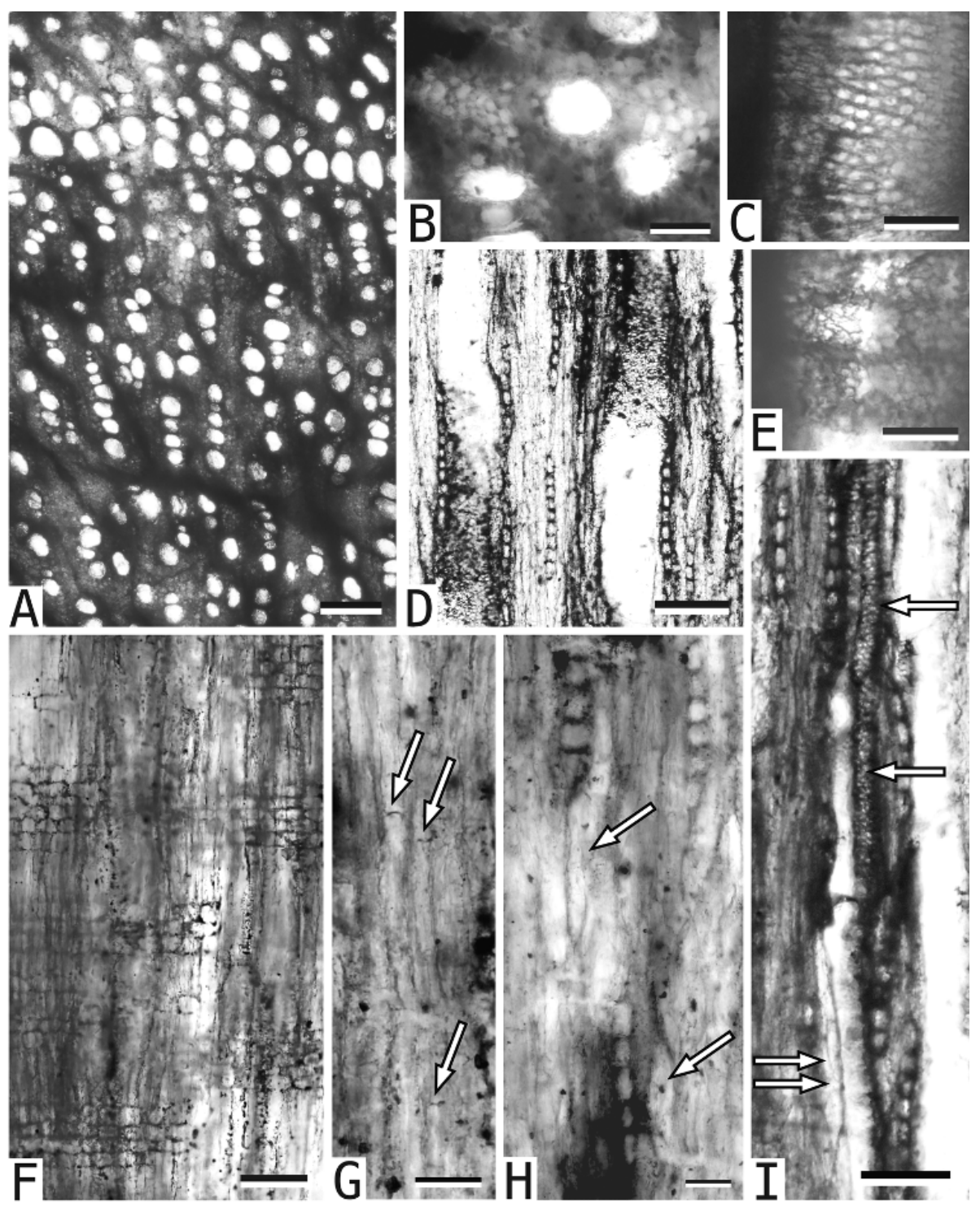

Figure 19. Lythraceae cf. Lagerstroemia III. - A: Semi-ring porous wood with vessels solitary and in short to long radial multiples, TS. - B: Parenchyma-like paratracheal fibers, TS. C: Alternate intervessel pits, TLS. - D: Uniseriate rays, TLS. - E: Vessel-ray pits similar to intervessel pits, RLS.-F: Rays of weakly procumbent to squarish cells, RLS. - G: Narrow fibers with septae (arrows), RLS. - H: Wider, parenchyma-like fibers (arrows), TLS. - I: Vascular tracheids (arrows), parenchyma-like fiber (double arrow), TLS. - Scale bars $=100 \mu \mathrm{m}$ in A, D, F; $50 \mu \mathrm{m}$ in $\mathrm{I} ; 25 \mu \mathrm{m}$ in $\mathrm{B}, \mathrm{C}, \mathrm{E}, \mathrm{G}, \mathrm{H}$. 
Affinities. These three wood types show combinations of characters (including semi-ring porosity, septate fibers, parenchyma-like fiber bands, rays exclusively uniseriate and composed of procumbent cells, and crystals in chambered fibers or axial parenchyma) unique to Lagerstroemia (Lythraceae) in the InsideWood database. Vessels in radial multiples; simple perforation plates; crowded, alternate intervessel pits; and scanty paratracheal parenchyma (Wood types II and III) are consistent with placement in this family (Baas \& Zweypfenning 1979). Vascular tracheids (Wood type III), although not described for Lagerstroemia, are found in several shrubby taxa of Lythraceae, where they occur as ground tissue in the latewood or associated with smaller vessels (Baas \& Zweypfenning 1979; Baas 1986). The fossils also show similarities to taxa in Sapindaceae with dimorphic fibers and rays of procumbent cells (Allophylus, Paranephelium). However, these taxa are not described as having fibers of two lengths and exhibit other differences from the fossils (longer parenchyma strands, growth rings marked by radially flattened latewood fibers). Some Mimosoideae (Leguminosae) also share a large number of characters with the fossil, but dimorphic fibers are very rare in this group.

Lagerstroemia is distinctive within Lythraceae in having well-developed bands of parenchyma or parenchyma-like fibers and homocellular rays and is also the only genus including species with ring- or semi-ring porous wood (Wood types II and III). The range of fiber lengths seen in Wood types I and II is consistent with Lagerstroemia species having dimorphic fibers (Baas \& Zweypfenning 1979). Dimorphic fibers of two lengths (occurring in Lawsonia, Physocalymma, and some Lagerstroemia) have been related to an evolutionary transition within the family from fibers through dimorphic fibers to parenchyma bands (Lagerstroemia in part; Baas \& Zweypfenning 1979). Rays of all procumbent cells, noted as diagnostic for Lagerstroemia within Lythraceae (but also occurring in Sonneratia, now included within the family), is likewise considered derived relative to the ray structure in other taxa (Baas and Zweypfenning 1979). Lawsonia and Physocalymma, for example, the only other taxa with dimorphic fibers, have heterocellular 2- to 3-seriate rays and uniseriate rays of all upright cells (Baas \& Zweypfennning 1979). Crystals (seen only in Wood types I and II) usually occur but can be absent or infrequent (Baas \& Zweypfenning 1979; InsideWood 2004-onwards). The individual wood types show additional characters suggesting affinity with Lagerstroemia. Uniseriate rays with short biseriate portions (Wood type I) are considered characteristic of the genus (Baas \& Zweypfenning 1979). Other features known to occur in the genus (Baas \& Zweypfenning 1979; P. Baas, pers. commun.) are gelatinous fibers and rays with intercellular spaces (Wood type I), bands of wide fibers with intercellular spaces (Wood type II), and marginal banding (Wood type III). Taxa with the tendency toward semi-ring or ring porosity also often have paratracheal bands linking the latewood vessels (L. hypoleuca Kurz, L. speciosa (L.) Pers.; InsideWood 2004-onwards), as seen in Wood type II. Specimens of Wood type III are relatively small, but vessel diameter is within the range of Lagerstroemia and other tree taxa within Lythraceae, which includes many herbs/subshrubs, shrubs, and small trees with much narrower vessels (Baas \& Zweypfenning 1979). 
Woody Lythraceae have a tropical to subtropical distribution in coastal and wetland areas as well as drier forests. Lagerstroemia includes $~ 50$ species of deciduous and evergreen trees and shrubs occurring across south Asia to Japan and Australia.

The fossil history of Lythraceae includes many records of Lagerstroemioxylon from the Tertiary of India and Southeast Asia (Gregory et al. 2009), but the family's history in South America, where there are 16 genera of herbs, shrubs and trees, is not well known (Graham 2013). Lagerstroemioxylon Mädler (1939, genus diagnosis in Kramer 1974), is not described as having dimorphic fibers. Included taxa, reviewed by Cheng et al. (2007), are variable with respect to porosity (from diffuse to ring or semi-ring porous), vessel arrangement, and banding pattern. Lagerstroemioxylon durum Mädler (1939), which lacks growth rings and is diffuse porous with a similar vessel distribution and banding pattern, is similar to Wood type I. As far as we are aware, the only fossil wood referred to Lagerstroemia or Lagerstroemioxylon described as having parenchyma-like fiber bands is Lagerstroemia odanianse (Choi et al. 2010) from the Miocene of Japan; this wood is also similar to Wood type I but has rings, narrower vessels, and heterocellular (weakly homocellular?) rays.

Although showing a close correspondence to Lythraceae - Lagerstroemia, the wood types are referred to Lagerstroemia because of the exclusively Old World distribution of the genus.

\section{CONCLUSIONS}

The fossils include a range of wood types, in particular, Anacardiaceae cf. Mangifera, Anacardium, Cynometra, Prioria, Cariniana, and Lythraceae cf. Lagerstroemia I, that were probably lowland tropical forest canopy elements based on their anatomy (having wide, sparsely occurring vessels, Baas et al. 2004) and also in most cases the characteristic habits of these taxa. Some of these taxa may also have been emergent trees, particularly Cynometra (based on the size of the fossil specimens), Cariniana, and Prioria. The many long, narrow permineralized tree trunks observed on the surface at the site (Woodcock et al. 2009) also indicate closed canopy forest of some stature. Other woods were probably understory elements judging from their anatomy (small, densely arranged vessels) and probable taxonomic affinities (e.g. those referred to Tabernaemontana and Dipterocarpaceae cf. Pseudomonotes). In addition, one liana is represented (Combretaceae cf. Thiloa) and one likely cauliflorous taxon (Cordia florifera). The diversity of anatomical and morphological/ecological types represented among the fossil dicots, as well as the presence and diversity of palms and other monocots (currently undescribed), suggests that the vegetation was lowland tropical forest.

Although the assemblage records the vegetation growing in a relatively small area, more than one vegetation type is represented. Presence of Avicennia indicates the existence of strand and possibly also backswamp or fluvial-corridor vegetation (based on the occurrence of the genus) growing in close proximity to a somewhat higherelevation, interfluvial forest represented by the majority of the dicot wood types. Taxa other than Avicennia that could have been components of wetter-adapted vegetation 
include Hura and Prioria, elements of seasonally flooded or riparian forest, and Cynometra, which occurs today in environments ranging from riparian to dry forest, as well as some of the monocot taxa.

A separate question is whether the fossil forest represents wet tropical forest (tropical rainforest) growing within the precipitation parameters for these forests as found currently (annual precipitation $>1800 \mathrm{~mm}$ and a dry season of no more than three months; Burnham \& Johnson 2004). As noted above, woods with sparsely arranged vessels are characteristic of evergreen canopy trees growing in mesic, lowland forest. On the other hand, the associated fossil leaves, although almost entirely entire-margined, are predominantly microphyllous to notophyllous with few mesophylls (Woodcock et al. 2009), in contrast with modern rainforests in which mesophylls and some megaphylls are the most prevalent leaf size categories (Wolfe 1979). Additionally, semi-ring porous woods, seen in Cordia (three wood types), Dalbergia, and Lagerstroemia (three wood types) among the taxa described here, are more prevalent than in modern rainforests and indicate a deciduous component to the flora (Boura \& De Francheschi 2007; Nath et al.2016). The prevalence of growth rings (11 out of 17 of the woods described here), which are rare in modern rainforests (Burnham \& Johnson 2004), is likewise notable. These considerations suggest that the assemblage represents lowland tropical forest with a dry aspect that may have been most similar to forests of the northern coast of South America or the periphery of the Amazon Basin growing where precipitation is more seasonal and lower than in present-day wet tropical forest.

\section{ACKNOWLEDGEMENTS}

The authors would like to thank Pieter Baas, Brent Berger, Marc Gottschling, Hugo Martinez-Cabrera, Imogen Poole, Teresa Terrazas, and four anonymous reviewers for their comments and suggestions. Assistance from Joel Norton (Clark University), Stanley Yankowski (Smithsonian Museum of Natural History) and Michaela Schmull (Harvard University) is also much appreciated. The first author would also like to thank faculty and students in the departments of Biology and Geography at the Universidad de Córdoba in Montería, Colombia, particularly Rubén Dario Godoy, for their interest and assistance. This research was supported by an American Philosophical Society grant to D. Woodcock and National Science Foundation grant 0403510 to D. Woodcock and H. Meyer.

\section{REFERENCES}

Acevedo Mallque M, Kikata Y. 1994. Atlas of Peruvian woods. Universidad Nacional Agraria La Molina/Universidad de Nagoya.

Ahmed B, Khan M, Rajput T, Khan KM. 1991. Mangiferoxylon pakistanicum sp. nov., a new fossil species of the family Anacardiaceae from Ranikot fort area [Pakistan]. Pakistan J. Bot. 23: 62-69.

Arango R, Green F. 2011. Salt damage to wood. US Forest Products Lab Techlines. Forest Products Laboratory, Madison WI.

Awasthi N. 1965 (1966). Fossil woods of Anacardiaceae from the Tertiary of South India. The Palaeobotanist 14: 131-143.

Awasthi N. 1984. Studies on some carbonised woods from the Neyveli Lignite deposits, India. Geophytology 14: 82-95.

Awasthi N, Prakash U. 1986 (1987). Fossil woods of Kingiodendron and Bauhinia from the Namsang beds of Deomali, Arunachal Pradesh. The Palaeobotanist 35: 178-183. 
Baas P. 1986. Wood anatomy of Lythraceae: additional genera (Capuronia, Galpinia, Haitia, Orias, and Pleurophora). Ann. Missouri Bot. Gard. 1986: 810-819.

Baas P, Ewers FW, Davis SD, Wheeler EA. 2004. Evolution of xylem physiology. In: Hemsley AR \& Poole I (eds.), The evolution of plant physiology: 273-295. Elsevier Ltd.

Baas P, Zweypfenning, RCV. 1979. Wood anatomy of the Lythraceae. Acta Bot. Neerl. 28: $117-155$.

Banks H, Gasson P. 2000. Pollen morphology and wood anatomy of the Crudia group (Leguminosae, Caesalpinioideae, Detarieae). Bot. J. Linn. Soc. 134: 19-59.

Barajas-Morales J. 1981. Descriptions and notes on the wood anatomy of Boraginaceae from western Mexico. IAWA Bull. n.s. 2: 61-67.

Bernal RA, Coradin V, Camargos J, Costa C, Pissarra J. 2011. Wood anatomy of Lecythidaceae species called "Tauari”. IAWA J. 32: 97-112.

Boura A, De Franceschi D. 2007. Is porous wood structure exclusive of deciduous trees? Comptes Rendus Palevol. 6: 385-391.

Brea M, Artabe AE, Franzese JR, Zucol AF, Spalletti LA, Morel EM, Veiga GD, Ganuza DG. 2015. Reconstruction of a fossil forest reveals details of the palaeoecology, palaeoenvironments and climatic conditions in the late Oligocene of South America. Palaeogeog. Palaeoclimatol. Palaeoecol. 418: 19-42.

Brea M, Zamuner AB, Matheos SD, Iglesias A, Zucol AF. 2008. Fossil wood of the Mimosoideae from the early Paleocene of Patagonia, Argentina. Alcheringa 32: 427-441.

Brea M, Zucol AF. 2006. Leños fósiles de Boraginaceae de la Formación Peñas Coloradas (Paleoceno superior), Puerto Visser, Chubut, Argentina. Ameghiniana 43: 139-146.

Burnham RJ, Johnson KR. 2004. South American palaeobotany and the origins of neotropical rainforests. Phil. Trans. Royal Soc. London B: 359: 1595-1610.

Caringella MA, Bergman BA, Stanfield RC, Ewers MM, Bobich EG, Ewers FW. 2014. Effects of phyllotaxy on biomechanical properties of stems of Cercis occidentalis (Fabaceae). Amer. J. Bot. 101: 206-210.

Carlquist S. 1988. Comparative wood anatomy: systematic, ecological, and evolutionary aspects of Dicotyledon wood. Springer, New York.

Cheng, Y, Li C, Jiang X, Wang Y. 2007. A new species of Lagerstroemioxylon (Lythraceae) from the Pliocene of Yuanmou, Yunnan, China. Acta Phytotax. Sinica 45: 315-320.

Choi S-K, Kim K, Jeong E-K, Terada K, Suzuki M, Uematsu H. 2010. Fossil woods from the Miocene in the Yamagata Prefecture, Japan. IAWA J. 31: 95-117.

Crawley M. 2001. Angiosperm woods from British Lower Cretaceous and Palaeogene deposits: with 16 tables. Special Papers in Palaeontology no. 66: 1-100. The Palaeontogical Association.

Dayanandan S, Ashton PS, Williams SM, Primack RB. 1999. Phylogeny of the tropical tree family Dipterocarpaceae based on nucleotide sequences of the chloroplast rbcL gene. Amer. J. Bot. 86: 1182-1190.

Den Outer RW, Schütz PR. 1981. Wood anatomy of some Sarcolaenaceae and Rhopalocarpaceae and their systematic position. Meded. Landb. Wagen. 81: 1-25.

Den Outer RW, Van Veenendaal WLH. 1995. Development of included phloem in the stem of Combretum nigricans (Combretaceae). IAWA J. 16: 151-158.

Détienne P, Jacquet P. 1983. Atlas d'identification des bois de l'Amazonie et des regions voisines. Centre Technique Forestier Tropical, Nogent-s-Marne. 640 pp.

Dong Z, Baas P. 1993. Wood anatomy of trees and shrubs from China. V. Anacardiaceae. IAWA J. 14: 87-102.

Espinoza de Pernía N, León HWJ. 2002. Estudio anatomico del leño de 56 especies de la subfamilia Papilionoideae (Leguminosae) en Venezuela. Rev. Forest. Venez. 46: 59-71. 
Fougère-Danezan M, Herendeen PS, Maumont S, Bruneau A. 2010. Morphological evolution in the variable resin-producing Detarieae (Fabaceae): do morphological characters retain a phylogenetic signal? Ann. Bot. 105: 311-325.

Franco MJ, Brea M. 2008. Leños fósiles de la Formación Paraná (Mioceno Medio), toma Vieja, Paraná, Entre ríos, Argentina: registro de bosques estacionales mixtos. Ameghiniana 45: 699-717.

Gasson P, Miller R, Stekel DJ, Whinder F, Ziemińska K. 2010. Wood identification of Dalbergia nigra (CITES Appendix I) using quantitative wood anatomy, principal components analysis and naïve Bayes classification. Ann. Bot. 105: 45-56.

Gasson P, Trafford C, Matthews B. 2003. Wood anatomy of Caesalpinioideae. In: Klitgaard BB \& Bruneau A (eds.), Advances in legume systematics, part 10, Higher Level Systematics: 63-93. Royal Botanic Gardens, Kew.

Gottschling M, Miller JS, Weigend M, Hilger HH. 2005. Congruence of a phylogeny of Cordiaceae (Boraginales) inferred from ITS1 sequence data with morphology, ecology, and biogeography. Ann. Missouri Bot. Gard. 92: 425-437.

Gottschling M, Weigend M, Hilger HH. 2016. Ehretiaceae. In: Kubitzki K (ed.), The families and genera of vascular plants, vol. XV, Eudicots. Springer, Berlin.

Gottwald H. 1983. Wood anatomical studies of the Boraginaceae (s.1.). I. Cordioideae. IAWA Bull. n.s. 4: 161-178.

Graham SA. 2013. Fossil records in the Lythraceae. Bot. Rev. 79: 48-145.

Gregory I. 1968. The fossil woods near Holley in the Sweet Home Petrified Forest, Linn County, Oregon. Oregon Department of Geology and Mineral Industries.

Gregory M, Poole I, Wheeler EA. 2009. Fossil dicot wood names - an annotated list with full bibliography. IAWA J., Suppl. 6. 220 pp.

Guleria JS. 1983 (1984). Occurrence of anacardiaceous woods in the Tertiary of western India. The Palaeobotanist 32: 35-43.

Guleria JS, Gupta SS, Srivastava R. 2001. Fossil woods from Upper Tertiary sediments of Jammu region (Jammu \& Kashmir), North-West India and their significance. The Palaeobotanist 50: $225-246$.

Gupta S, Agarwal M. 2008. Wood anatomy of Anacardiaceae from India with special reference to the systematic position of Rhus. IAWA J. 29: 79-106.

Herbst R. 2007. La Paleoxilología en la Argentina. Historia y desarrollo. Publicación Electrónica de la Asociación Paleontológica Argentina 11: 57-71.

Heubl GR, Gaviria JC, Wanner G. 1990. A contribution to the taxonomy and evolution of Cordia (Boraginaceae) and allied general. Bot. Jahrb. Syst. 112: 129-165.

Hoorn C, Weaseling FP, ter Steege H, Bermudez MA, Mora A, Sevink J, Sanmartín I, SanchezMeseguer A, Anderson CL, Figueiredo JP, Jaramillo C. 2010. Amazonia through time: Andean uplift, climate change, landscape evolution, and biodiversity. Science 330: 927 931.

IAWA Committee. 1989. IAWA list of microscopic features for hardwood identification. IAWA Bull. n.s. 10: 219-332.

InsideWood. 2004-onwards. Published on the Internet. http://insidewood.lib.ncsu.edu/.

Jaramillo C, Rueda MJ, Mora G. 2006. Cenozoic plant diversity in the Neotropics. Science. 311: 1893-1896.

Klaassen RKWM. 1999. Wood anatomy of the Sapindaceae. IAWA J., Suppl. 2. 214 pp.

Kramer K. 1974. Die Tertiären Hölzer südost-Asiens (unter Ausschluss der Dipterocarpaceae). 1 \& 2. Palaeontographica B 144: 45-181.

Lens F, Baas P, Jansen S, Smets E. 2007. A search for phylogenetically informative wood characters within Lecythidaceae s.1. Amer. J. Bot. 94: 483-502. 
Lens F, Endress ME, Baas, P, Janssen S, Smets E. 2008. Wood anatomy of Rauvolfioideae (Apocynaceae): A search for meaningful non-DNA characters at the tribal level. Amer. J. Bot. 95: 1199-1215.

León HWJ. 2003. Anatomia de la madera de 9 especies del genero Cordia L. (Boraginaceae) que crecen en Venezuela. Rev. Forest. Venez. 47: 83-84.

León HWJ, Chavarri R. 2006. Anatomía xilemática del tallo de 8 especies de la subfamilia Euphorbioideae (Euphorbiaceae) en Venezuela. Rev. Fac. Agron. 106: 1-12.

Lewis G, Schrire B, Mackinder B, Lock M (eds.). 2005. Legumes of the world. Royal Botanic Gardens, Kew.

Mädler K. 1939. Die pliozäne Flora von Frankfurt am Main. Abh. Senckenberg. Naturf. Ges. 1939: 1-202.

Maurin O, Chase MW, Jordaan M, Van der Bank M. 2010. Phylogenetic relationships of Combretaceae inferred from nuclear and plastid DNA sequence data: implications for generic classification. Bot. J. Linn. Soc. 162: 453-476.

Mehrotra RC, Bera SK, Basumatary SK, Srivastava G. 2011. Study of fossil wood from the Middle-Late Miocene sediments of Dhemaji and Lakhimpur districts of Assam, India and its palaeoecological and palaeophytogeographical implications. J. Earth Syst. Sci. 120: 681-701.

Melandri JL, Espinoza de Pernía N. 2009. Wood anatomy of tribe Detarieae and comparison with tribe Caesalpinieae (Leguminosae, Caesalpinioideae) in Venezuela. Rev. Biol. Trop. 57: 303-319.

Mennega AMW. 2005. Wood anatomy of the subfamily Euphorbioideae - A comparison with subfamilies Crotonoideae and Acalyphoideae and the implications for the circumscription of the Euphorbiaceae. IAWA J. 26: 1-68.

Metcalfe CR, Chalk L. 1950. Anatomy of the dicotyledons, Vols. 1 \& 2. Oxford University Press.

Miller RB, Détienne P. 2001. Major timber trees of Guyana. Wood anatomy. Tropenbos International, The Netherlands.

Morton CM. 1995. A new genus and species of Dipterocarpaceae from the Neotropics. II. Stem anatomy. Brittonia 47: 237-247.

Nath CD, Munoz F, Pélissier R, Burslem DF, Muthusankar G. 2016. Growth rings in tropical trees: role of functional traits, environment, and phylogeny. Trees 23: 1-23.

Navarro P, Pajuelo D, Woodcock D, Ordoño E. 2012. Nuevos aportes sobre la geología del Bosque Petrificado Piedra Chamana, Sexi-Cajamarca. XVI Peruvian Geological Congress; Sociedad Geologica del Peru. 5 pp.

Prakash U, Bande MB. 1977 (1980). Some more fossil woods from the Tertiary of Burma. The Palaeobotanist 26: 261-278.

Prakash U, Tripathi PP. 1969 (1970). Fossil woods from the Tertiary of Hailakandi, Assam. The Palaeobotanist 18: 20-31.

Raigemborn MS, Brea M, Zucol AF, Matheos SD. 2009. Early Paleogene climate at mid latitude in South America: Mineralogical and paleobotanical proxies from continental sequences in Golfo San Jorge basin (Patagonia, Argentina). Geologica Acta 7: 125-145.

Rajput KS, Patil VS. Rao KS. 2009. Development of included phloem of Calycopteris floribunda Lamk. (Combretaceae). J. Torrey Bot. Soc. 136: 302-312.

Ramanujam CG. 1960. Silicified woods from the Tertiary rocks of South India. Palaeontographica B 106: 99-140. 
Richter HG, Dallwitz MJ. 2000-onwards. Commercial timbers: descriptions, illustrations, identification, and information retrieval. Version: 25th June 2009. http://delta-intkey.com

Richter HG, Krause VJ, Muche C. 1996. Dalbergia congestiflora Standl.: wood structure and physico-chemical properties compared with other Central American species of Dalbergia. IAWA J. 17: 327-341.

Salard M. 1961 (1962). Euphorbioxylon bridelioides n. sp., bois fossile du Perou. Cr 86e Congr. nat. Soc. sav., Montpellier, Sci: 581-591.

Schönfeld G. 1947. Hölzer aus dem Tertiär von Kolumbien. Abh. Senckenbergischen Naturf. Ges. 475: 1-53.

Selmeier A. 2003. First record of a Lecythidaceae wood (Carinianoxylon brasiliense gen. et sp. nov.) from the Tertiary of the New World (Brazil, Rio Paranaiba). Zitteliana A 43: $171-178$.

Sonsin JO, Gasson P, Machado SR, Caum C, Marcati R. 2014. Atlas da diversidade de madeiras do Cerrado Paulista. Editoria Fepaf. 423 pp.

Staples LW. 1950. Cubic pseudomorphs of quartz after halite in petrified wood [Oregon]. Amer. J. Sci. 248: 124-136.

Sun Q, Suzuki M. 2000. Wood anatomy of mangrove plants in Iriomote Island of Japan: a comparison with mangrove plants from lower latitudes. Acta Phytotax. Geobot. 51: $37-55$.

Sutherland JI. 2003. Miocene petrified wood and associated borings and termite faecal pellets from Hukatere Peninsula, Kaipara Harbour, North Auckland, New Zealand. J. Roy. Soc. NZ. 33: 395-414.

Terrazas TS. 1994. Wood anatomy of the Anacardiaceae: ecological and phylogenetic interpretation. Unpubl. Diss., University of North Carolina at Chapel Hill. 321 pp.

Tomlinson PB. 1994. The botany of mangroves. Cambridge University Press. 419 pp.

Van Hinsbergen DJJ, de Groot LV, van Schaik SJ, Spakman W, Bijl PK, Sluijs A, Langereis CG, Brinkhuis H. 2015. A paleolatitude calculator for paleoclimate studies (model version 1.2). PLoS One 2015 Jun 10; 10 (6): e0126946.

Van Vliet GJCM. 1976. Radial vessels in rays. IAWA Bull. n.s. 3: 35-37.

Van Vliet GJCM. 1979. Wood anatomy of the Combretaceae. Blumea 25: 141-223.

Van Vliet GJCM, Baas P. 1984. Wood anatomy and classification of the Myrtales. Ann. Missouri Bot. Gard. 71: 783-800.

Vatanparast M, Klitgard BB, Adema FACB, Pennington RT, Tersukazu Y, Kajita T. 2013. First molecular phylogeny of the pantropical genus Dalbergia: implications for infrageneric circumscription and biogeography. South African J. Bot. 89: 143-149.

Weeks A, Zapata F, Pell SK, Daly DC, Mitchell JD, Fine PV. 2014. To move or to evolve: contrasting patterns of intercontinental connectivity and climatic niche evolution in "Terebinthaceae" (Anacardiaceae and Burseraceae). Front. Genetics 5: 1-20.

Wheeler EA. 2011.InsideWood - a web resource for hardwood anatomy. IAWA J. 32: 199-211.

Wheeler EA, Baas P. 1992. Fossil wood of the Leguminosae: a case study in xylem evolution and ecological anatomy. In: Herendeen PS \& Dilcher DL (eds.), Advances in legume systematics. 4. The fossil record: 281-301. Royal Botanical Garden, Kew.

Wheeler EA, Manchester SR. 2002. Woods of the Eocene Nut Beds flora, Clarno Formation, Oregon, USA. IAWA J., Suppl. 3. 188 pp.

Wilf P, Cúneo NR, Escapa IH, Pol D, Woodburne MO. 2013. Splendid and seldom isolated: the paleobiogeography of Patagonia. Ann. Rev. Earth Planet. Sci. 41: 561.

Wilf P, Johnson KR, Cúneo NR, Smith ME, Singer BS, Gandolfo MA. 2005. Eocene plant diversity at Laguna del Hunco and Río Pichileufú, Patagonia, Argentina. Amer. Nat. 165: $634-650$. 
Wing SL, Herrera F, Jaramillo CA, Gomez-Navarro C, Wilf P, Labandeira CC. 2009. Late Paleocene fossils from the Cerrejón Formation, Colombia, are the earliest record of Neotropical rainforest. Proc. Nat. Acad. Sci. 106: 18627-18632.

Wolfe JA. 1979. Temperature parameters of humid to mesic forests of eastern Asia and relation to forests of other regions of the northern hemisphere and Australasia. USGS Prof. Paper 1106. US Gov. Printing Office.

Woodcock D, Meyer H, Dunbar N, McIntosh W, Prado I, Morales G. 2009. Geologic and taphonomic context of El Bosque Petrificado Piedra Chamana (Cajamarca, Peru). Geol. Soc. Amer. Bull. 121: 1172-1178.

Zachos J, Pagani M, Sloan L, Thomas E, Billups K. 2001. Trends, rhythms, and aberrations in global climate 65 Ma to present. Science 292: 686-693.

Zamski E. 1979. The mode of secondary growth and the three-dimensional structure of the phloem in Avicennia. Bot. Gaz. 140: 67-76.

Accepted: 22 November 2016

Associate Editor: Imogen Poole 